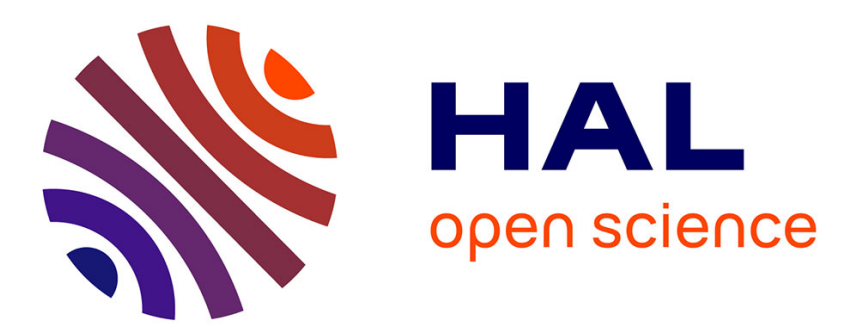

\title{
Number and adjectives: the case of French Activity and Quality Nominals.
}

\author{
Delphine Beauseroy, Marie-Laurence Knittel
}

\section{To cite this version:}

Delphine Beauseroy, Marie-Laurence Knittel. Number and adjectives: the case of French Activity and Quality Nominals.. Studia Linguistica, 2012, 66 (3), pp.207-244. hal-00951762

\section{HAL Id: hal-00951762 \\ https://hal.science/hal-00951762}

Submitted on 25 Feb 2014

HAL is a multi-disciplinary open access archive for the deposit and dissemination of scientific research documents, whether they are published or not. The documents may come from teaching and research institutions in France or abroad, or from public or private research centers.
L'archive ouverte pluridisciplinaire HAL, est destinée au dépôt et à la diffusion de documents scientifiques de niveau recherche, publiés ou non, émanant des établissements d'enseignement et de recherche français ou étrangers, des laboratoires publics ou privés. 


\section{NUMBER AND ADJECTIVES: THE CASE OF FRENCH ACTIVITY AND QUALITY NOMINALS}

\section{INTRODUCTION}

This article is dedicated to the examination of the role of Number with regards to adjective distribution in French. We focus on two kinds of abstract nouns: activity nominals and quality nominals. Both display particular behaviours with regards to adjective distribution: activity nominals need to appear as count nouns to be modified by qualifying adjectives; concerning quality nominals, they are frequently introduced by the indefinite $u n(e)$ instead of the partitive article ( $d u$ / de la) when modified. Our analysis of adjectives is based on the idea that they can have two uses, which correlate with syntactic and semantic restrictions and are distinguishable on semantic grounds. Adjectives are understood either as taxonomic, i.e. as denoting a subkind of the modified noun, or as qualifying, in which case they express a property of the noun. Whereas taxonomic adjectives qualify as direct modifiers in the sense of Cinque (2010), qualifying adjectives behave either as direct or as indirect modifiers.

To account for the restrictions on the modification on activity and quality nominals, along the lines of Borer (2005), we suggest that the Num head un(e) is responsible for the partitioning of the noun's referent, which in turn enables the presence of a qualifying adjective.

The article is organized as follows. In Section 2, we define and illustrate the class of activity nominals (2.1.) and describe their behaviour with regards to both taxonomic and qualifying adjectival modification, paying particular attention to the fact that they must occur in count use to accept qualifying (vs. taxonomic) modification (2.2.). Consequently, we provide a syntactic analysis of both kinds of adjectival modification based on the presence vs. absence of Num(ber)P (2.3.), and relying on Cinques's (2010) approach to adjective attachment. In Section 3 we define quality nominals, and then compare them to activity nominals with regards to modification. We show that quality nominals accept various types of articles when modified, but that the choice of the article relates to the interpretation of the adjective (3.2.), these observations also match the description of activity nominals. In Section 4, we provide an articulated syntactic analysis of the distribution of the articles with various classes of adjectival modifiers in the presence of quality and activity nominals. In Section 5, we draw the conclusion of our article.

\section{ACTIVITY NOMINALS}

\subsection{Definition}

Activity nominals (Van de Velde 1995; Flaux \& Van de Velde 2000; Haas \& Huyghe 2007; Haas, Huyghe \& Marin 2008) are nouns which are morphologically related to verbs denoting Activities, i.e. durative and atelic processes (Vendler 1967; Verkuyl 1972; Smith 1991), as illustrated in (1):
(1)a. danse $_{\mathrm{N}} /$ danser $_{\mathrm{V}}$ 'dance' 'to dance'
b. marche $_{\mathrm{N}} /$ marcher $_{\mathrm{V}}$ 'walk' 'to walk'
c. natation $_{\mathrm{N}} /$ nager $_{\mathrm{V}}$ 'swimming' 'to swim'
d. cuisine $_{\mathrm{N}} /$ cuisiner $_{\mathrm{V}}$ 'cooking' 'to cook'

In what follows, we will limit our attention to nouns related to intransitive verbs. Such nouns usually occur in structures such as (2) and (3) that exhibit a habitual reading:

(2)a. DP faire partitive article Activ.N.
b. Max fait $\{\mathrm{du}$ jardinage Max does \{PART.ART.MASC gardening /
de la PART.ART.FEM
natation / de la marche\}. swimming/ PART.ART.FEM walking\}


'Max does some \{gardening / swimming / walking\}'.

(3)a. DP pratiquer definite article Activ.N.

b. Max pratique $\{$ le jardinage / la natation / la marche $\}$ tous les week-end. Max practises \{the gardening/ the swimming/ the walking\} all the week ends Lit.: 'Max practices \{gardening /swimming / walking\} on weekends'.

According to Pivault (1994), in structures like (2) and (3), the DP subject is understood as an Agent, and the verb faire as a light verb, i.e. it lacks semantic content. Consequently, the semantic predicate of the sentence is the activity nominal itself. Note also that the non-countable character of activity nominals is revealed by the use of the so-called 'partitive article', which is the form of the indefinite article used to introduce mass nouns (cf. $d u$ vin '(some) wine' / de la bière '(some) beer'). As shown by the following examples, the atelic character of the verbal predicate is maintained by the corresponding noun, which is compatible only with PPs introduced by pendant 'for' but not by en 'in':

a. Max a fait $\{\mathrm{du}$ jardinage / de la

Max has done \{PART.ART.MASC gardening/ PART.ART.FEM

$/ *$ en deux heures $\}$.

$/ *$ in two hours $\}$.

'Max did (some) \{gardening / walking\} \{for two hours / *in two hours\}.'

b. Zoé a pratiqué \{la danse/la natation\} \{pendant dix ans / *en dix ans\}. Zoe has practiced \{the dancing / the swimming \{for ten years / * * in ten years\}.

'Zoe has practiced \{dancing / swimming\} \{for 10 years / *in ten years\}.'

Another context in which activity nominals are particularly frequent is the subject position of generic sentences (5) (see Heyd \& Knittel 2009) and the object position of psychological verbs (6):

(5) a. \{Le jardinage / la natation $\}$ est un loisir répandu. \{the gardening / the swimming $\}$ is a hobby common ' $\{$ Gardening / swimming $\}$ is a common hobby.'

b. \{L'escalade / la danse $\}$ développe la souplesse. \{the climbing / the dancing improves the flexibility

' Rock climbing / dancing\} improves suppleness.'

(6) a. Je déteste le jardinage.

I hate the gardening

'I hate gardening.'

b. Les Français adorent la marche.

the French love the walk

'French people love walking.'

In fact, even nouns that are not related to verbs - and which usually refer to entities, abstract (7), concrete (8), and even animate (9) - can receive an activity interpretation when they occur as objects of the light verbs faire and pratiquer (Heyd \& Knittel 2009). In such cases, they usually refer to sports, sciences or arts (Pivault 1994). An important fact is that, in (8a) and (9a), the nouns piano 'piano' and cheval 'horse' appear as mass nouns, and not under their usual count forms (8b, 9b):

(7) La syntaxe donne des maux de tête.

the syntax gives INDEF.PL. headaches

'Syntax gives (people) headaches.' 
(8) a. Paul fait du piano depuis dix ans.

Paul does PART.ART.MASC piano for ten years

'Paul has been playing the piano for ten years.'

vs.: b. Ces pianos sont lourds.

these pianos are heavy.

'These pianos are heavy.'

(9) a. Marie a fait du cheval cet été.

Marie has done PART.ART.MASC horse this summer

'Mary went riding this summer.'

vs.: b. Ces chevaux sont noirs.

these horses are black

'These horses are black.'

We will now examine adjectival modification of activity nominals.

\subsection{Adjectival modification of activity nominals}

This subsection is dedicated to the examination of the properties of modified activity nominals. We first distinguish two types of adjective uses from both semantic and syntactic points of view. We then show that adjectival modification of activity nominals by qualifying adjectives depends on their use as count nouns.

\subsubsection{Two kinds of adjectival modification}

In what follows, we will consider two kinds of adjectival modification: 'qualifying' and 'taxonomic' modification $^{2}$ (see Knittel 2005). In the first type, adjectives used as qualifying modifiers express an extra property of the noun and accept predicative use and adverbial modification, as in example (10). In the other kind of modification, 'taxonomic' adjectives refer to subkinds of the head noun, can only be used attributively and cannot be modified by adverbs (11). The following examples illustrate the difference between these uses with contrasting interpretations:

$$
\begin{aligned}
& \text { a. un gâteau (très) léger } \\
& \text { a cake (very) light } \\
& \text { 'a (very) light cake' }
\end{aligned}
$$

b. Ce gâteau est (très) léger.

this cake is (very) light

'This cake is (very) light.'

$$
\begin{aligned}
& \text { (11) a. un gâteau (*très) sec } \\
& \text { a cake (very) dry } \\
& \text { Lit.: 'a dry cake' (i.e. a biscuit) } \\
& \neq \quad \text { b. Ce gâteau est (*très) sec. } \\
& \text { this cake is (very) dry } \\
& \text { Lit.: 'This cake is (*very) dry.' }
\end{aligned}
$$

In examples (10), the adjective léger 'light' can be modified by an adverb and exhibits predicative use. Semantically, it expresses an 'accidental' property of a cake individual. In (11), conversely, the adjective sec 'dry' cannot be modified by an adverb, and has no predicative use. It is also semantically different from léger in (10), in that it enables reference to a subkind of the noun it modifies or to members of this subkind, that is un gâteau sec 'a biscuit'. Taxonomic adjectives thus qualify as subsective modifiers.

However, the examples in (11) are not syntactically ill-formed. Rather, the adjective is possible in predicative use provided it is understood as denoting a (accidental) property of a given cake (e.g. a 
stale cake), and not as a type of cake. This example shows that 'taxonomic' and 'qualifying' should not be understood as referring to adjective classes. Rather, they describe adjective uses, since adjectives generally exhibit both behaviours (see McNally \& Boleda 2004; Knittel 2005 for similar observations about relational adjectives).

The taxonomic vs. qualifying use of a given adjective can also be distinguished by the fact that, when the adjective has a corresponding quality noun, the noun / adjective alternation is possible only when the adjective is used qualifyingly (12), as shown by Fradin \& Kerleroux (2003, 2009). In contrast, taxonomic uses of the same adjectives do not alternate with deadjectival nouns as illustrated by (13).
a. une agression sauvage a aggression brutal
'a brutal aggression'
b. la sauvagerie de cette agression the brutality of this aggression 'the brutality of this aggression'
c. Cette agression a été (très) sauvage this aggression has been (very) brutal Lit: 'This aggression has been very brutal.'

(13) a. une fleur sauvage a flower wild 'a wild flower'

b. *la sauvagerie de cette fleur the wildness of this flower Lit: 'the wildness of this flower'

c. *Cette fleur est (très) sauvage this flower is (very) wild Lit: 'This flower is very wild.'

In the following section, we examine the distribution of adjectives with activity nominals.

\subsubsection{Qualifying modification}

Let us now examine how the adjectives in the uses described above behave when combined with activity nominals.

The examples in (14) reveal that activity nominals can be modified by qualifying adjectives when the nouns denote specific entities or events, or when they refer to concrete objects (15):

(14) a. Lors du spectacle, elle a exécuté \{une $/$ des $\}$ danse(s) gracieuse(s). during the show, she has performed $\{\mathrm{a} /$ some $\}$ dance(s) graceful(PL) 'During the show, she performed $\{\mathrm{a} /$ some $\}$ graceful dance(s).'

b. Les marches fatigantes qu' ils ont faites les ont épuisés. the walks tiring(PL) that they have done them have exhausted Lit: 'The tiring walks they took exhausted them.'

(15) Elle a acheté \{une moto rapide/ un piano blanc/ un cheval noir\}. she has bought \{a motorbike fast / a piano white/ a horse black\} 'She bought $\{$ a fast motorbike / a white piano / a black horse $\} . '$

However, the following examples show that qualifying modification is impossible for activity nominals when they occur in their typical syntactic configurations (see 2.1.). 


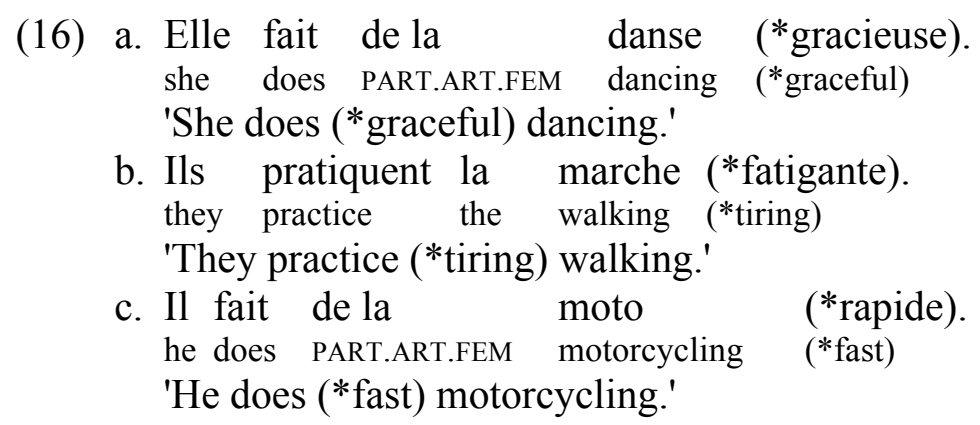

The examples in (14-15) and (16) also display another major morphosyntactic difference: in (16), the activity nominals necessarily take a narrow scope with operators such as negation (17), a fact that signals their non-specific character. Second, they cannot be separated from the light verb on which they depend and, consequently, cannot occur as subjects of the passive construction (18):

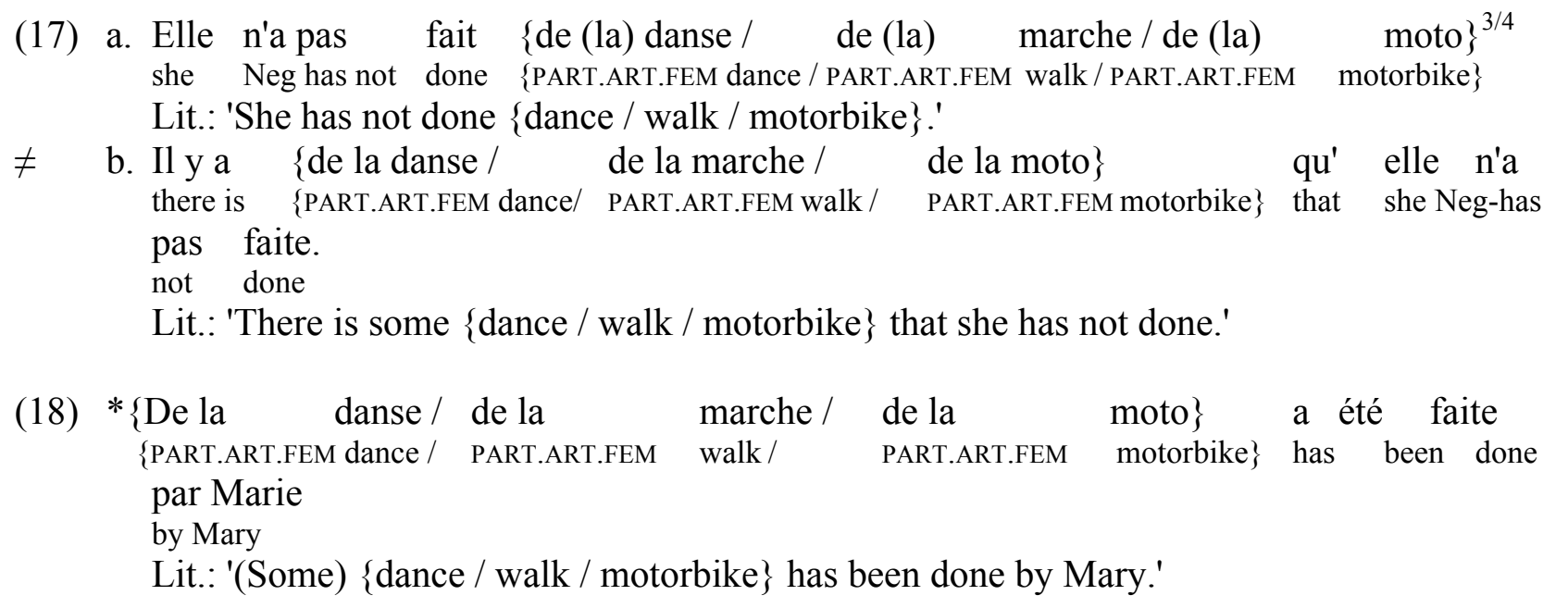

Narrow scope and adjacency with a verbal head are properties reminiscent of those displayed by incorporated elements (see Bittner 1988, de Hoop 1992, van Geenhoven 1998, Farkas \& de Swart 2003, and Mathieu 2004, 2006 for French), which are also characterized by the lack of number inflection or variation ${ }^{5}$.

A first hypothesis to account for the impossibility of qualifying modification is to consider that it is directly linked to the incorporated status of the nominals (see Knittel 2009, 2010 for such observations). However, the examples in (19) show that qualifying modification is also impossible in generic use:

(19) a. La danse (*gracieuse) développe la souplesse.

the dance (*graceful) develops the suppleness

'(*Graceful) dancing improves suppleness.

b. La marche (*fatigante) provoque des crampes.

the walk (*tiring) causes INDEF.PL cramps.

'(*Tiring) walking causes cramps.'

c. La moto (*rapide) est un sport dangereux.

the motorcycling $(*$ fast $)$ is a sport dangerous

'(*Fast) motorcycling is a dangerous sport.'

We thus conclude that, for activity nominals, qualifying modification is restricted to specific, i.e. non-incorporated and non-generic, contexts. Now, generic and incorporated uses share another 
peculiarity: that of excluding count activity nominals, even when those are available in other contexts (see (14-15)).
a. * $\{$ Les marches / les motos / les danses $\}$ sont un loisir répandu. \{the walk-PL / the motorcycling-PL / the dance-PL $\}$ are a hobby common
b. *Elle pratique \{les marches / les motos / les danses\} she practises \{the walk-PL / the motorbike-PL/ the dance-PL\}

We can consequently hypothesize that, in the case of activities, number inflection is a syntactic reflex of specificity. Since only specific use allows qualifying modification, one only finds modified number-inflected (vs. mass) activity nominals.

\subsubsection{Taxonomic modification}

As suggested above, taxonomic adjectives are used to refer to subtypes. This is shown by the following examples, which also reveal that only taxonomic modification is possible in generic DPs whose lexical head is an activity nominal:

(21) a. La danse orientale est une sorte de danse. the dancing oriental is a kind of dancing 'Oriental dance is a kind of dance.'

vs.: b. \# La danse gracieuse est une sorte de danse. the dancing graceful is a kind of dancing \# 'Graceful \{dancing / dance $\}$ is a kind of \{dancing / dance $\}.$ '

(22) a. La syntaxe formelle est une branche de la syntaxe. the syntax formal is a branch of the syntax. 'Formal syntax is a branch of syntax.'

vs.: b. \# La syntaxe difficile est une branche de la syntaxe. the syntax difficult is a branch of the syntax.

\# 'Difficult syntax is a branch of syntax.'

From a semantic point of view, this fact is easily explained if we consider that generic NPs refer to types, not to individuals. In such a case, possible modifications are limited to taxonomic adjectives which enable reference to subtypes. It seems that no adjective expressing an extra, i.e. accidental, property can modify generic NPs.

The following examples indicate that taxonomic adjectives are indeed possible in sentences such as (24), where they occur as subjects of generic sentences as well as in (23), exhibiting activity nominals in their incorporated use ${ }^{6}$ :

(23) a. La danse orientale développe la souplesse. the dancing oriental develops the flexibility

'Oriental dancing improves suppleness.'

b. La marche rapide provoque des crampes. the walking fast causes INDEF.PL cramps. '(Fast) walking causes cramps.'

c. La syntaxe formelle donne des maux de tête. the syntax formal gives INDEF.PL headaches

'Formal syntax causes headaches.'

(24) a. Elle fait de la danse orientale. she does PART.ART.FEM dancing oriental

'She does oriental dancing.' 
b. Ils pratiquent la marche rapide.

they practice the walking (fast)

'They practice fast walking.'

c. Elle fait de la syntaxe formelle.

she does PART.ART.FEM syntax formal

Lit.: 'She does formal syntax.'

We can conclude that taxonomic modification is possible in any context where activity nominals are found, and does not rely on the distinctions ( \pm specific, \pm incorporated, \pm number-inflected) to which qualifying adjectives are sensitive.

The following subsection is dedicated to a syntactic analysis of this phenomenon.

\subsection{Syntactic analysis}

In this section, we provide a syntactic analysis to account for the contrast between qualifying and taxonomic modification of activity nominals. Our analysis relies on the structural relationship between the FPs hosting adjectival projections (Cinque 2010) and NumP (Ritter 1991, Carstens 1991, Valois 1991), and / or vP (Harley 2009).

\subsubsection{The syntactic structure of activity NPs}

Recall from the preceding examples that activity nominals need to occur in count use to enable qualifying modification. Along the lines of Ritter (1991), Carstens (1991), and Valois (1991), let us assume that NumP is the projection encoding number variability (i.e. singular vs. plural). Thus, a DP (Abney 1987) whose head is a count (activity) nominal, such as marche(s) 'walk(s)' or danse(s) 'dance(s)' (14), contains a NumP in its functional structure.

Along the lines of Shlonsky (2004), we also assume that there is no N movement in the DP (see also the arguments against $\mathrm{N}$ movement raised by Lamarche 1991, Laenzlinger 2005, Haegeman 2003 , Knittel 2005) ${ }^{7}$. Rather, in order to account for the noun's number variability, we assume that NP moves to Spec,NumP.

However, as we saw previously, activity nominals can either occur as mass or as count nouns. This variability can be simply explained by the analyzes of Borer (2005), Kwon \& Zribi-Hertz (2004), and Zribi-Hertz \& Glaude (2007), who argue that Number is an optional projection which is realized only for count nouns.

Since activity nominals describe events, we also assume that their functional structure contains an event projection vP, along the lines of Harley (2009) and Alexiadou (2009) (see also Davidson 1967). Finally, in agreement with Picallo (2008) and Iordachioaia \& Soare (2009) in the case of event nominals, we consider that projections of nouns are characterized by a ClassP, which encodes their nominal character, and checks the noun's Gender features.

Consequently, danse 'dance' or marche 'walk' will be represented as in (25) when in count use, and as in (26) when used as?mass nouns; instead of a movement of NP to NumP, we assume that the whole ClassP moves to Spec,NumP. 
$(25)$

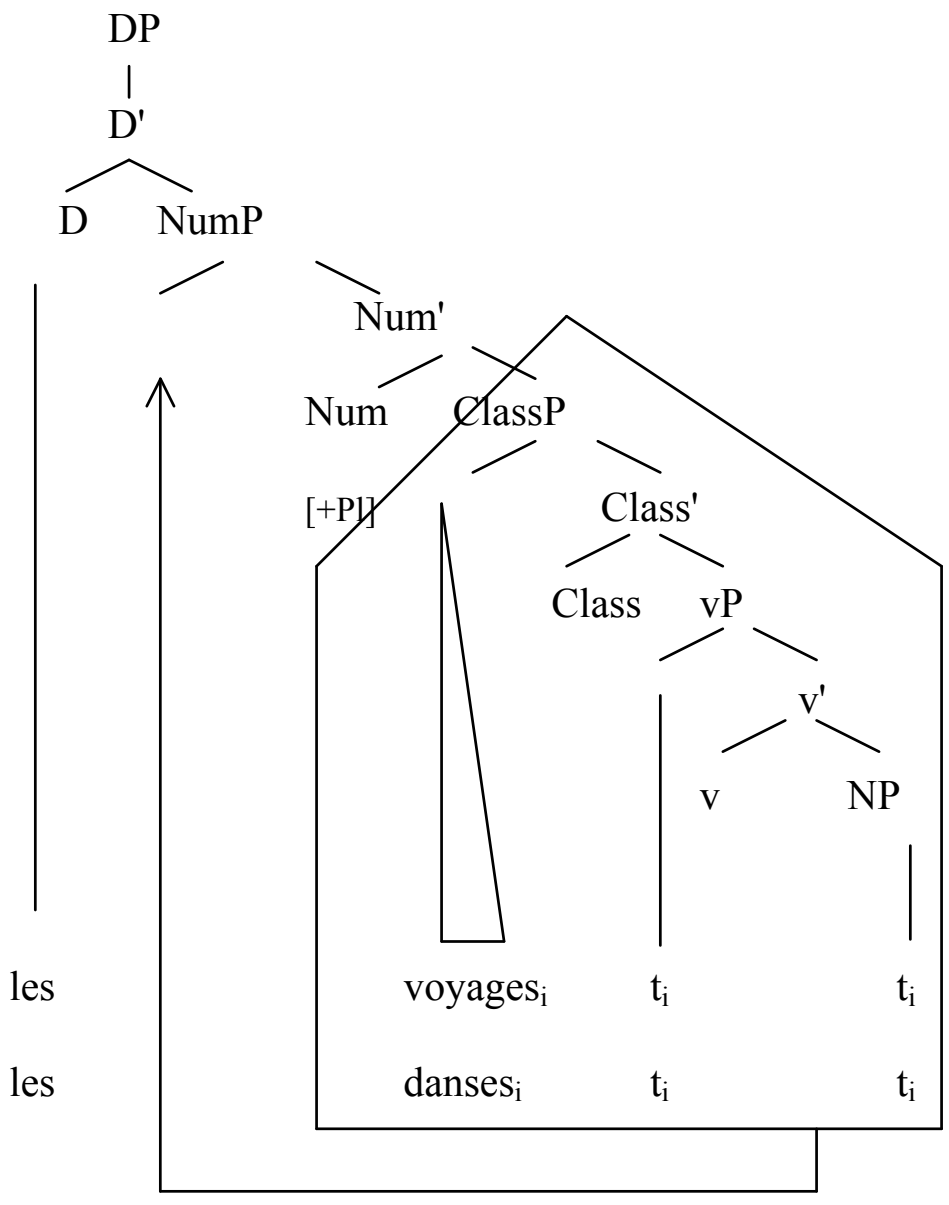

(26)

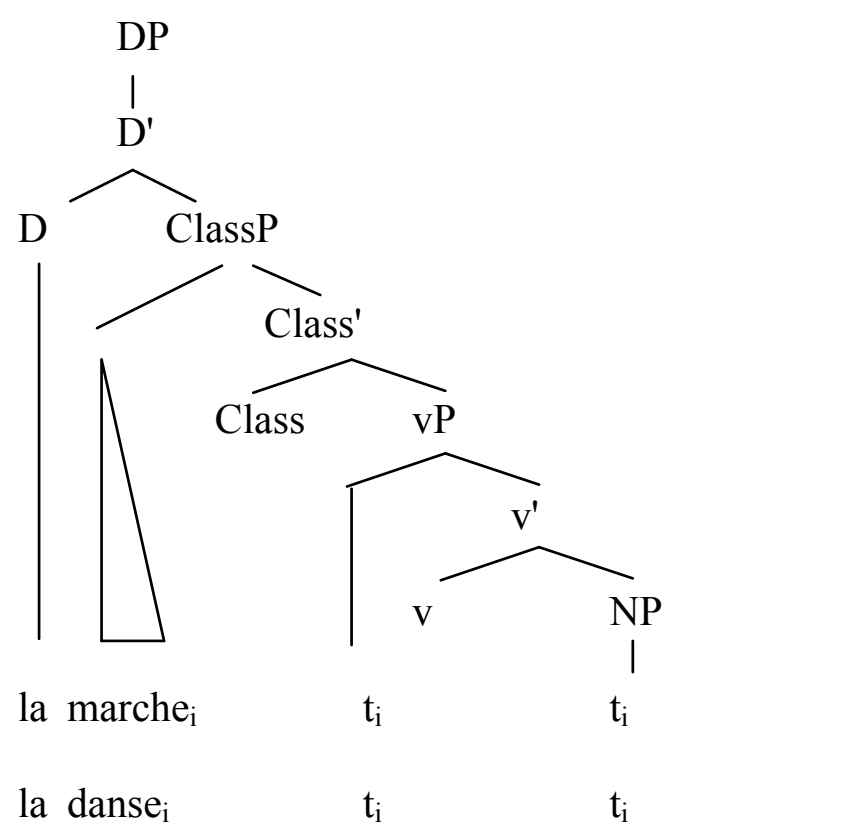

\subsubsection{Adjective attachment}

Recall from section 2.2. that qualifying modification is possible only for activity nominals that display number inflection, that is, if NumP is present in the DP structure; in contrast, taxonomic modification is independent of NumP. 
To account for this variation, we hypothesize that the projections hosting qualifying adjectives merge above NumP, whereas those hosting taxonomic adjectives merge above ClassP. More precisely, we claim that the projections of adjectives in qualifying use syntactically select NumP as their complement, whereas those of adjectives in taxonomic use select ClassP as their complement. If we adopt Cinque's (2010) hypothesis that AdjPs are merged in the specifiers of F(unctional)Ps, the resulting representations are:

(27) a. Qualifying modification:

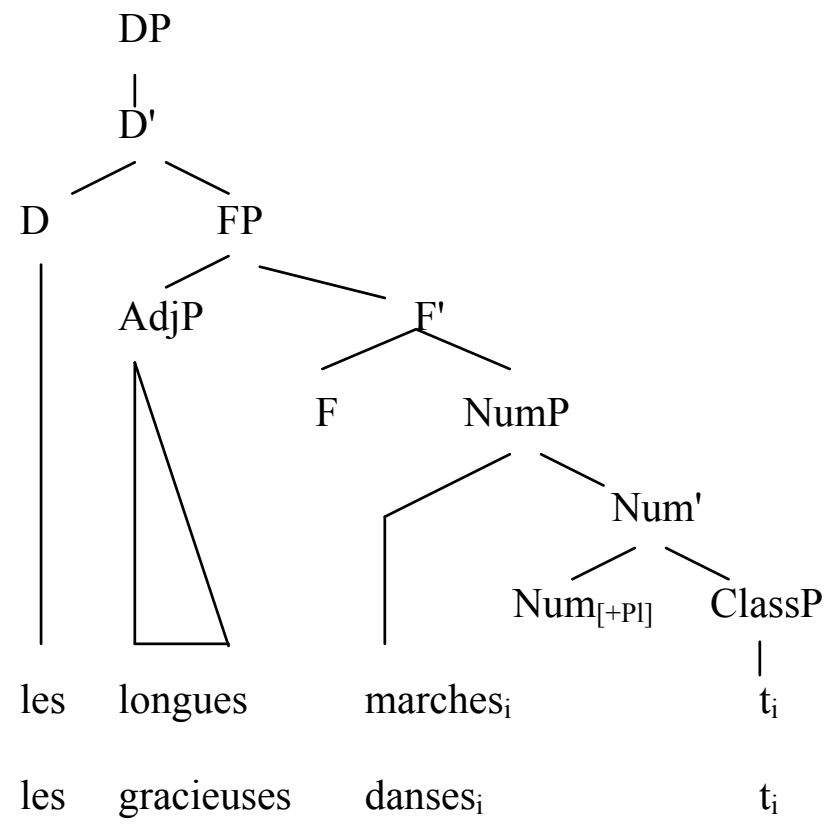

b. Taxonomic modification:

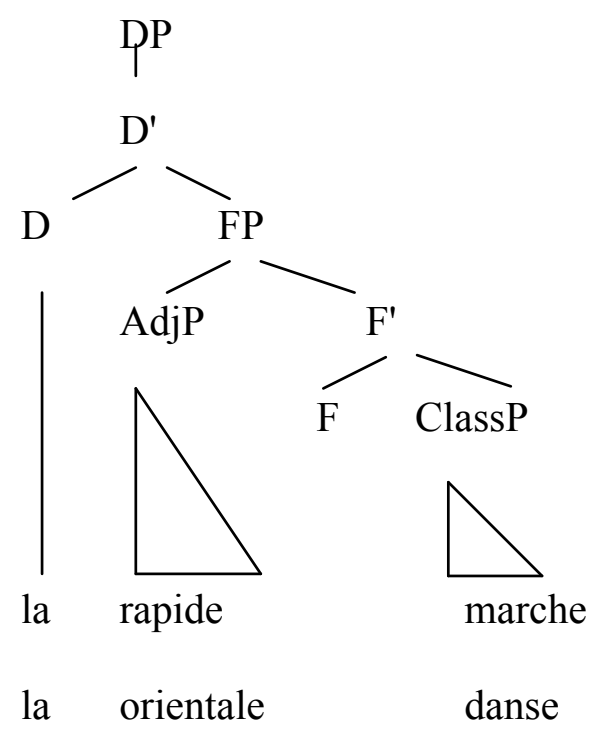

Since adjectives such as rapide 'fast' and orientale 'oriental' necessarily appear postnominally (28ab), and that fatiguante 'tiring' and gracieuse 'graceful' can also occur in this position (28c-d), we need to account for their placement. 
(28) a. $\{$ de la / une $\}$ (*orientale) danse (orientale)

ssome / a\} (*oriental) dance (oriental)

b. $\quad$ de la / une $\}$ (*rapide) marche (rapide)

\{some / a\} (*fast) walk (fast)

c. une (gracieuse) danse (gracieuse)

a (graceful) dance (graceful)

d. une (épuisante) marche (épuisante)

a (exhausting) walk (exhausting)

Consequently, like in Cinque's (2010) analysis, we consider that the FPs hosting adjectives are dominated by other FPs to which the ClassP / NumP is moved:

(29) a. Qualifying modification:

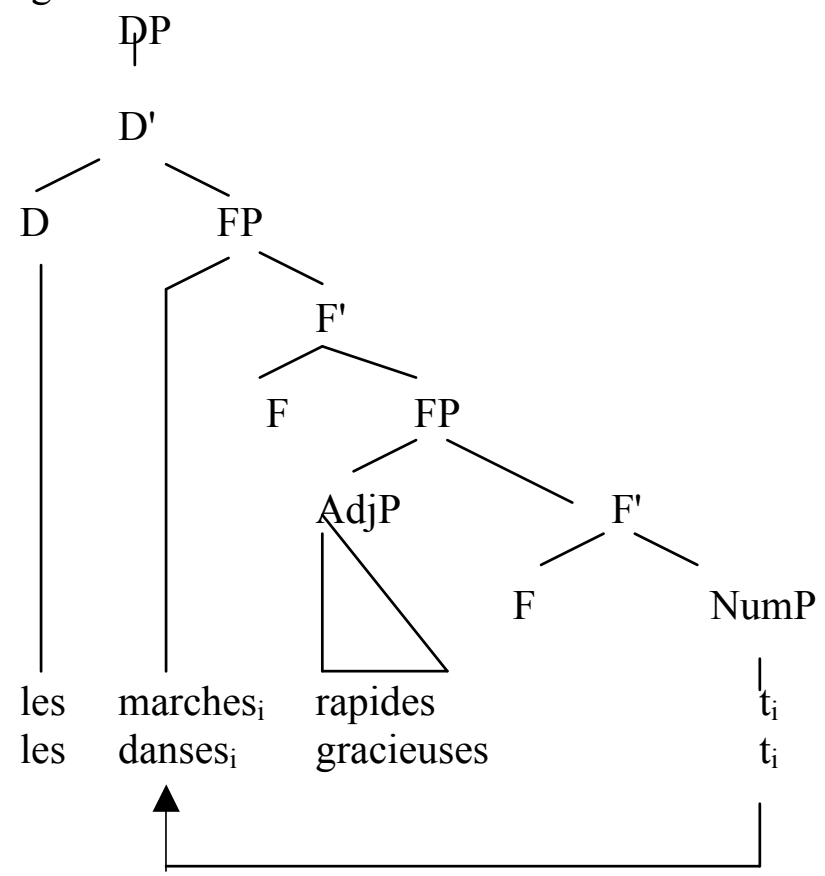

b. Taxonomic modification:

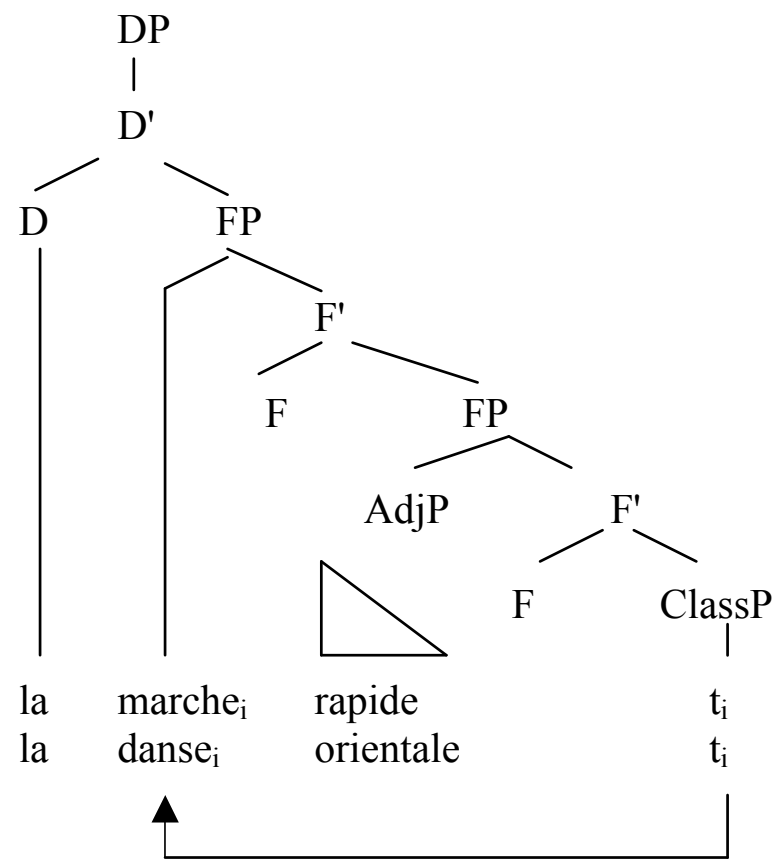


Consider now examples (30-31):

(30) a. Elle a exécuté une danse orientale $\mathrm{T}_{\mathrm{Tax}}$ gracieuse $_{\text {Qual }}$. she has performed a dance oriental graceful 'She performed a graceful oriental dance.'

b. *Elle a exécuté une danse gracieuse ${ }_{\text {Qual }}$ orientale $_{\text {Tax }}$. she has performed a dance graceful oriental

(31) a. Ils ont participé à une marche rapide Tax $_{\text {épuisante }}$ Qual. $_{\text {. }}$ they have taken part to a walk fast exhausting

Lit.: 'They took part in an exhausting fast walk.'

b. *Ils ont participé à une marche épuisante ${ }_{\text {Qual }}$ rapide $_{\text {Tax }}$. they have taken part to a walk exhausting fast

These examples reveal that taxonomic adjectives necessarily occur closer to nouns than qualifying adjectives. This adjacency requirement is in fact described by Sproat and Shih (1990) and Cinque (2010), who rely on similar examples to distinguish direct from indirect adjectival modification.

According to these authors, adjectives pertaining to direct modification occur closer to the noun than those expressing indirect modification. They also exhibit various properties that are reminiscent of those displayed by the taxonomic adjectives described above. In particular, they may lack predicative use, which is also a property of taxonomic adjectives (11). The following examples illustrate this fact with activity nominals:

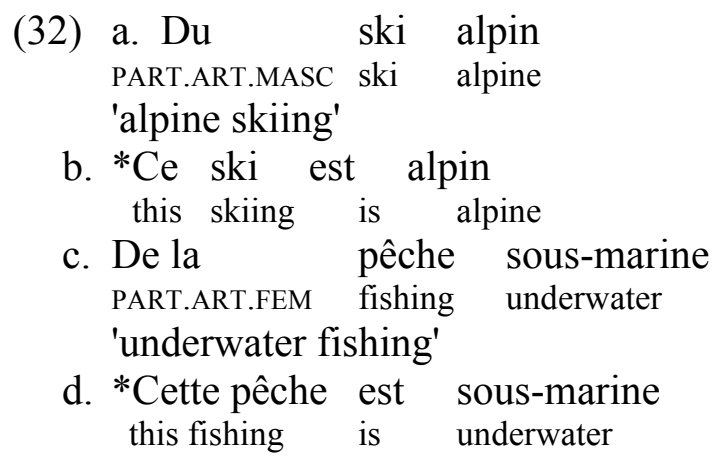

As noted by Cinque (2010), after Bolinger (1967), direct adjectives modify the noun's reference, which is exactly the case of taxonomic adjectives.

Finally, Cinque notes that direct modification can give rise to idiomatic [N-A] readings. Even if this is not exactly the case here, one can observe that, in ski alpin 'alpine skiing', the adjective does not mean 'pertaining to the Alps', as is usually the case (cf. la flore alpine 'alpine flora', i.e. the flora of the Alps), but refers to downhill skiing. In the same way, in a string such as pêche automnale 'autumnal fishing', the adjective takes an individual level interpretation, since it refers to a kind of fishing that usually occurs in Autumn and displays specific characteristics, but cannot be used to describe a fishing party that accidentally occurred in Autumn.

Finally, the need to distinguish between these two kinds of modifiers is confirmed by the fact that they cannot be coordinated:

$\begin{array}{cccl}\text { (33) a. *une danse orientale } & \text { et } & \text { gracieuse } \\ \text { a dance oriental } & \text { and } & \text { graceful } \\ \text { b. *une marche rapide } & \text { et } & \text { épuisante } \\ \text { a walk fast } & \text { and } & \text { exhausting }\end{array}$ 
Considering now adjectives such as gracieuse and épuisante, the first hypothesis is that they are indirect modifiers. However, several facts prevent such an analysis. First, these adjectives can also occur prenominally (see (28)), a property characteristic of direct modification:
a. une gracieuse danse orientale a gracious dance oriental
b. une épuisante marche rapide a exhausting walk fast
'an exhausting fast walk'

Second, some of these adjectives also display an evaluative value that is superimposed on their original meaning. For instance, in une danse remarquable 'a remarkable dance', the adjective is primarily understood as 'great' rather than as 'noteworthy'. Thus, remarquable corresponds to a positive evaluation. In the same way, une course incroyable 'an incredible race' means 'a great race' rather than 'an unbelievable race'. Such adjectives are considered as direct modifiers in Cinque's (2010) analysis. On the other hand, an adjective such as inattendu 'unexpected', which can only be understood as 'that was not expected' and occurs necessarily postnominally, is analyzed as an indirect modifier. As will be discussed in Section 4, adjectives of the inattendu type as well as those of the gracieux and remarquable type necessarily occur with un:

$$
\begin{aligned}
& \{\text { une } / * \text { de la }\} \text { danse } \text { gracieuse / remarquable / inattendue } \\
& \{\mathrm{a} / \text { *PART.ART.FEM }\} \text { dance } \text { graceful/ remarkable/ unexpected\} } \\
& \text { 'a dance }\{\text { graceful / remarkable / unexpected\}' }
\end{aligned}
$$

The above observations enable us to draw the conclusion that the taxonomic vs. qualifying contrast does not parallel the direct vs. indirect opposition put forward by Sproat \& Shih (1990) and Cinque (2010); rather, if taxonomic adjectives qualify as direct modifiers, qualifying adjectives may be either direct or indirect modifiers. Consequently, the presence vs. absence of NumP is not the appropriate criterion for opposing direct vs. indirect modification. Rather, as shown by (35), the distinction is between activity nominals introduced by the partitive article, which only accept taxonomic modification, and those introduced by the indefinite article, which combine with direct and indirect qualifying adjectives.

Our analysis led us to the same conclusion as Larson (1998), namely that the non-intersective reading of adjectives arises when the adjective applies to the event component of the nominal.

Consider the representation in (36), from Cinque (2010), which illustrates the basic ordering of adjectival projections (the FP have been numbered to facilitate reference, I.M. and D.M. standing for 'indirect modification' and 'direct modification' respectively): 
(36)

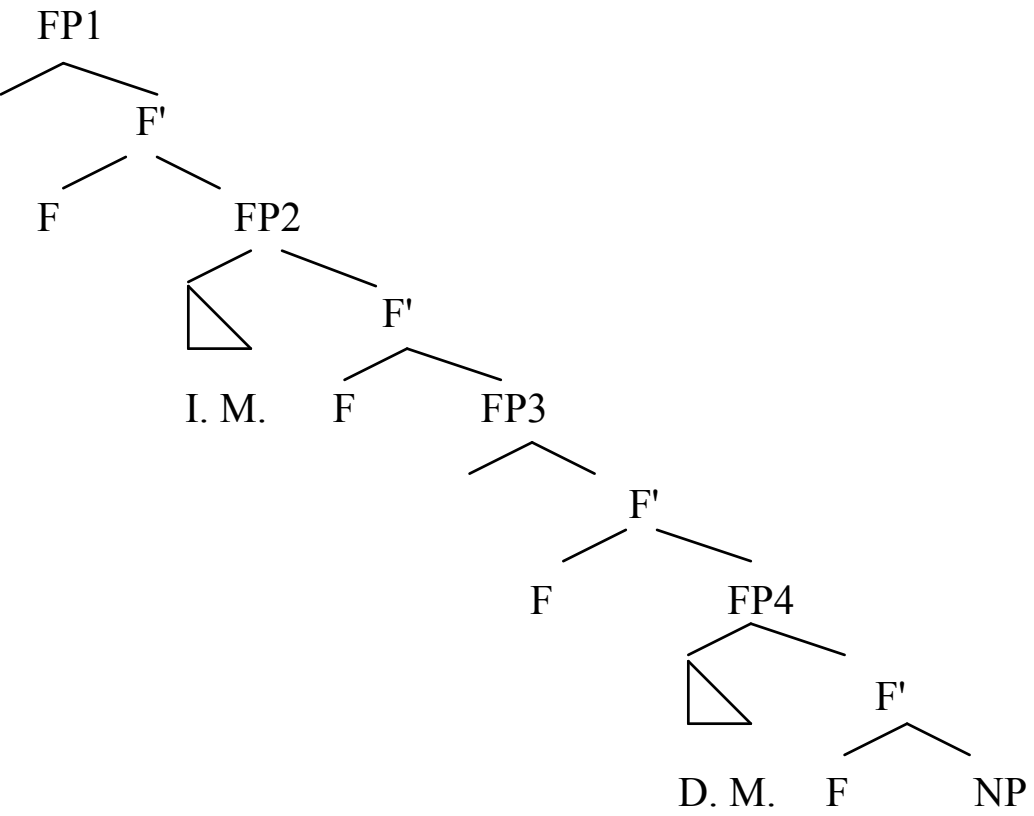

We can now suggest that NumP is in fact inserted in the above structure under FP4, and that FPs hosting taxonomic modification merge between NumP and ClassP in the case of activity nominals (the projections of indirect modification have been omitted in (37)): 
(37)
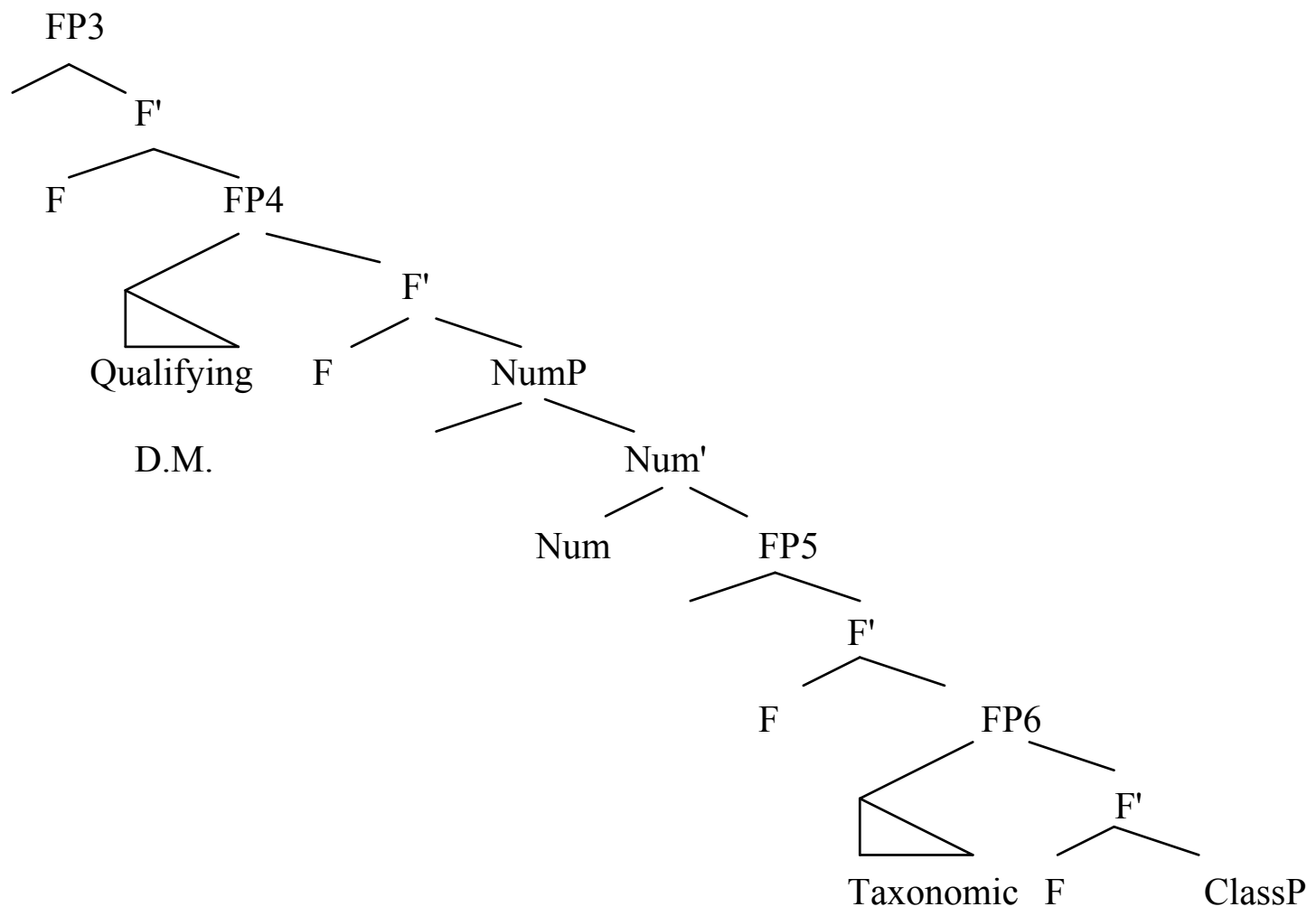

D.M.

If we assume that the type of movement at work here is remnant movement, as Shlonsky (2004) and Cinque (2010) suggest, the above representations accurately account for the placement of adjectives with activity nominals. Since taxonomic adjectives are postnominal, we assume a movement of ClassP to Spec, F5P. If ClassP remains in this position, qualifying adjectives, if any, will appear left

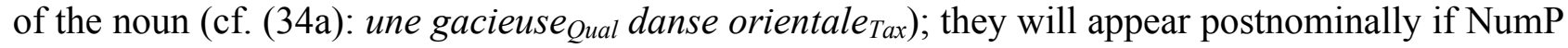
moves to Spec,F3P ((30a): une danse orientale $_{T a x}$ gracieuse $\left._{\text {Qual }}\right)$. Note that predicative use is restricted to adjectives that merge in Spec,F4P or above, that is, as indirect modifiers.

We can now examine quality nominals.

\section{QUALITY NOMINALS}

\subsection{Definition}

According to Rainer (1989), who introduced the term, quality nominals are nouns morphologically built on adjectives (36a-b), and denoting properties. Along the lines of Van de Velde (1995), and Flaux \& Van de Velde (2000), we also include nouns from which adjectives can be morphologically built (38d) in this class, since both types refer to properties:
a. agressivité $_{\mathrm{N}} /$ agressif $_{\mathrm{Adj}}$ 'aggressiveness' / 'brutal'; 'aggressive'
c. imprudence N $_{\mathrm{N}} /$ imprudent $_{\mathrm{Adj}}$ 'imprudence'/ 'imprudent'
b. clarté N $^{\text {/ }}$ clair $_{\text {Adj }}$ 'brightness' / 'bright'
d. courage $_{\mathrm{N}} /$ courageux $_{\mathrm{Adj}}$ courage / 'courageous', 'brave'

Like activity nominals, quality nominals frequently occur as objects of light verbs:
(39) a. Paul \{a/possède $\}$ une grande sensibilité. Paul \{has/possesses\} a great sensitivity Lit.: 'Paul \{has / possesses\} a great sensitivity.' 


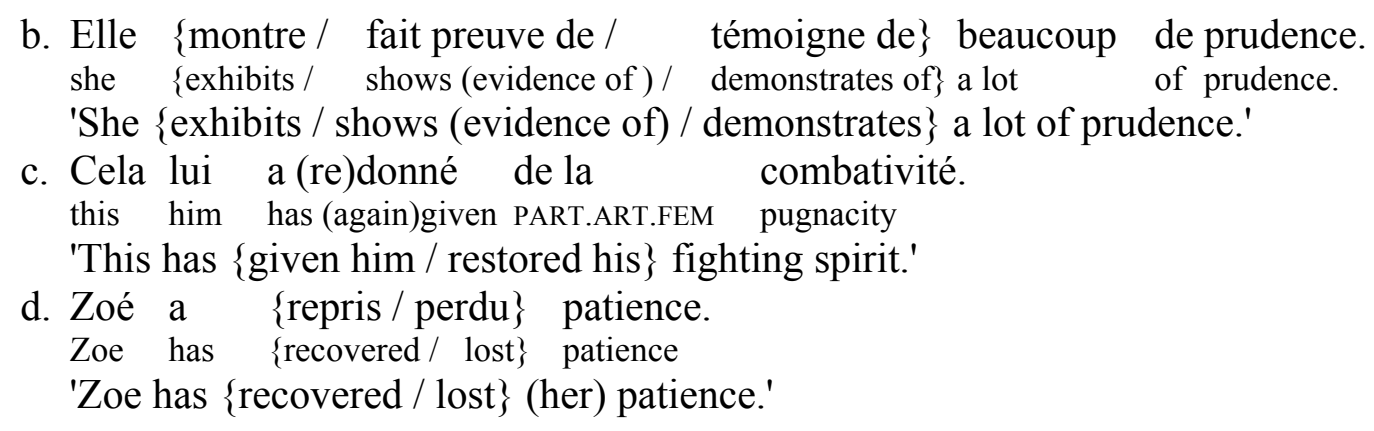

The nominals under investigation here are those that display aspectual properties; i.e., they share the aspectual properties of the predicate to which they are related. Since they are paired with adjectival predicates, which are stative, they also refer to states (Beauseroy 2009). Consequently, they lack temporal span, and can only vary in intensity (Van de Velde 1995; Flaux \& Van de Velde 2000). This is shown by the fact that, when modifying a quality nominal, beaucoup 'much' can only have an intensive meaning (Obenauer 1983), like très 'very' with the corresponding adjective (see (40)). Conversely, when beaucoup modifies dynamic verbal or nominal predicates, such as those denoting activities, it can only receive a temporal (longtemps 'for a long time') or habitual (souvent 'often') interpretation $(41)^{8}$ :
(40) a. beaucoup de \{courage/ patience / éloquence/ imprudence\} a lot of \{courage/ patience/ eloquence / imprudence\}
'a lot of \{courage / patience / eloquence / imprudence\}'
$=\mathrm{b}$. être très \{courageux / patient / éloquent / imprudent\} to be very \{brave/ patient/ eloquent/ imprudent\}
'to be very \{brave / patient / eloquent / imprudent\}'
$\neq$ c. être \{souvent / longtemps\} \{courageux / patient/ éloquent / imprudent\}
to be \{often/ for a long time\} \{brave/ patient/ eloquent/ imprudent\}
'to be $\{$ brave / patient / eloquent /imprudent $\}$ \{often / for a long time $\}$ '
(41) a. beaucoup de \{danse/ patinage/ ski/ marche\} a lot of \{dancing/ skating/ skiing/ walking\} 'a lot of \{dancing / skating / skiing / walking \}'
$=$ b. $\{$ danser $/$ patiner $/$ skier $/$ marcher $\}$ \{souvent / longtemps \{to dance / to skate / to ski / to walk\} \{often / for a long time\} ' $\{$ to dance / to skate / to ski / to walk\} \{often / for a long time\}'
$\neq$ c. $\{$ danser / patiner / skier/ marcher $\}$ intensément \{to dance / to skate / to ski / to walk\} intensely ' $\{$ to dance / to skate / to ski / to walk\} intensely'

Finally, like activity nominals, quality nominals are mass nouns; however, some also have a count use in which they refer to concrete or abstract manifestations of quality (Van de Velde 1995, Flaux \& Van de Velde 2000, Beauseroy 2009), as shown by the (b) examples (42-44):

(42) a. Max a montré de l' imprudence.

Max has shown PART.ART.FEM imprudence

'Max has shown (some) imprudence.'

b. Max a commis deux impudences.

Max has committed two imprudences.

Lit.: 'Max committed two imprudences.' (i.e. two imprudent acts) 
(43) a. Zoé a manifesté de la méchanceté.

Zoé has exhibited PART.ART.FEM wickedness

'Zoé has exhibited (some) wickedness.'

b. Zoé a proféré plusieurs méchancetés.

Zoe has uttered several wickednesses

Lit.: 'Zoe uttered several wickednesses.' (i.e. several wicked, nasty things)

(44) a. Paul a montré de la négligence.

Paul has shown PART.ART.FEM carelessness

'Paul has shown (some) carelessness.'

b. Les négligences de Paul ont été critiquées.

the carelessnesses of Paul have been criticized

Lit.: 'Paul's carelessnesses have been criticized.' (i.e. his careless acts)

Consequently, like in the case of activity nominals, we assume that quality nominals display NumP only in count use.

When in mass use, quality nominal can be considered as incorporated elements, in the same way as an activity nominal. The following examples show that they also take a narrow scope with negation, and cannot be separated from the light verb on which they depend by passivation:

(45) a. Il n'a pas montré de courage.

he Neg-has not shown PART.ART.MASC courage

'He did not show courage.'

$\neq$ b. Il y a du courage qu' il n' a pas montré.

there is PART.ART.MASC courage that he Neg-has not shown

Lit.: 'There is some courage that he did not show.'

(46) ??Du courage a été montré par Marie.

PART.ART.MASC courage has been shown by Mary

Lit.: '(Some) courage has been shown by Mary.'

\subsection{Modification of quality nominals}

In the literature, it is reported (Van de Velde 1995; Flaux \& Van de Velde 2000; Beauseroy \& Knittel 2007) that quality nominals do not accept modification when introduced by partitive articles, that is, in their mass use. Instead, when such nominals appear with adjectival modification, the indefinite article $u n(e)$ 'a', must be used (47). The same holds true when a relative clause or a bare complement appears with the quality nominal (48-49).

(47) a. Ce professeur a $\{*$ de la / une $\}$ patience extraordinaire. this teacher has \{PART.ART.FEM / a\} patience extraordinary

Lit.: 'This teacher has an extraordinary patience.'

b. Zoé a manifesté $\left\{{ }^{*}\right.$ de la/ une $\}$ très grande gentillesse. Zoe has shown $\{$ PART.ART.FEM/a\} very great kindness.

Lit.: 'Zoe has shown a very great kindness.'

c. Max a montré \{*de la/ une $\}$ méchanceté diabolique envers Marie. Max has shown \{PART.ART.FEM/a\} wickedness devil-like towards Mary

Lit.: 'Max has shown a devil-like wickedness towards Mary.'

(48) Zoé a montré $\{*$ de la / une $\}$ subtilité [qui nous a impressionnés $]_{\text {Rel }}$. Zoe has shown \{PART.ART.FEM/a\} shrewdness [that us has impressed]

Zoe has shown a shrewdness [that impressed us]. 
(49)

Il a $\{*$ de la / une $\}$ patience d' ange.

he has \{PART.ART.FEM/ a\} patience of angel

Lit.: 'He's got a patience of angel.'

It should be noted that modified quality nominals introduced by un(e) still keep their abstract, property denotation, and do not refer to acts or words (see Section 4.1.). As a consequence, they appear in the same contexts as their mass equivalents. Moreover, they do not pluralize (50). The presence of $u n(e)$ is actually a syntactic reflex of the presence of a modifier, as shown by the fact that this article cannot be used to introduce an unmodified quality nominal (51):

(50) *Zoé a montré \{des/ deux/ plusieurs $\}$ très grandes gentillesses.

Zoé has shown \{INDEF.PL/ two/ several $\}$ very great kindnesses.'

Lit.: 'Zoé has shown \{some / two / several\} very great kindnesses.'

(51) *Elle a montré un courage.

she has shown a courage

Lit.: 'She has shown a courage.'

However, even if grammars do not mention this possibility, Kupferman $(2004,87)$ observes that modified quality nominals may be introduced by partitive articles in the context of copulative sentences (52). (53) shows that such strings, where un(e) is also possible ${ }^{9}$, are also found in other contexts, including negative sentences like $(53 \mathrm{c})$ :

$\begin{array}{lllll}\text { a. Ce discours, c' était } & \{\text { de la } / \quad * u n e\} & \text { grande éloquence. } \\ \text { this talk, } & \text { it was }\end{array}$

Lit.: 'This talk, it was great eloquence.' (i.e. Doing this talk, it was showing great eloquence.)

(Kupferman 2004, 87)

b. Ces agressions, c' est \{de la/ *une\} violence gratuite. these aggressions it is $\{$ PART.ART.FEM $/ * a$ a violence pointless

Lit.: 'These aggressions, they are pointless violence.'

(53) a. Ils ont fait preuve $\{$ de / d'une $\}$ vraie gratitude they have made proof $\{$ of / of a $\}$ true gratitude

'They showed (a) true gratitude.'

b. Ce jour-là, il a manifesté \{de la / une\} méchanceté gratuite. that day-DEM, he has demonstrated \{PART.ART.FEM/ a\} wickedness gratuitous

'That day, he demonstrated (a) gratuitous wickedness.'

c. Ils n'ont pas montré \{de / une $\}$ fausse modestie. they Neg-have not shown \{PART.ART. / a false modesty

'They did not show (a) false modesty.'

We can thus conclude that, in contrast to what is traditionally assumed, quality nominals do not necessarily need to be introduced by $u n(e)$ when modified. Still, the above examples raise several questions: is there any difference between structures introduced by $u n(e)$ and those introduced by the partitive article? And why should quality nominals behave differently from activity nominals with regards to adjectival modification?

These questions are addressed in the following sections.

\section{ADJECTIVAL MODIFICATION PATTERNS}

In this section, we show that the modification patterns observed for activity nominals also apply to quality nominals, and that the same interactions between modification type and the mass / count 
distinction are observed. We then examine the properties of modified nominals introduced by un(e), and consider the hypotheses put forward by Kupferman (2004) and Kleiber (2003). Finally, we propose an appropriate syntactic treatment for modified nominals with the indefinite article, based on Cinque $(2008,2010)$.

\subsection{Qualifying modification}

Recall from section 2.2.1. that activity nominals can be modified by qualifying adjectives when they occur as count nouns, i.e. when they are dominated by NumP. Like activity nominals, some quality nominals may also occur as count nouns (42b-44b). In such a case, they refer either to external manifestations of the quality in question, through words (42b) or actions (43-44b) or are used to designate concrete objects characterized by the property in question, as in (54):

(54) J' ai admiré les beautés du paysage.

I have admired the beauties of.the landscape

'I have admired the beauties of the landscape.' (i.e. the beautiful things in the landscape)

As expected from the behaviour of activity nominals, quality nominals also allow qualifying modification when they occur as count nouns.

(55) a. Il a commis une méchanceté impardonnable.

he has committed a wickedness unforgivable

Lit.: 'He has committed an unforgivable wickedness.'

b. Elle a proféré d' incroyables absurdités.

she has uttered INDEF.PL incredible absurdities

Lit.: 'She uttered incredible absurdities.'

c. J' ai admiré les sublimes beautés du paysage.

I have admired the sublime beauties of.the landscape

Lit.: 'I have admired the sublime beauties of the landscape.'

The qualifying nature of the modifiers in the above examples is confirmed by the fact that they can occur predicatively and can accept adverbial modification.

(56) a. Ces méchancetés sont (vraiment) impardonnables.

these wickednesses are (truly) unforgivable

Lit.: 'These wickednesses are truly unforgivable.' (i.e. these wicked acts)

b. Les absurdités qu' elle a proférées sont (franchement) incroyables.

the absurdities that she has uttered are (frankly) incredible

Lit.: 'The absurdities that she uttered are (frankly) incredible.'

c. Les beautés du paysage sont (simplement) sublimes.

the beauties of.the landscape are (simply) sublime

Lit.: 'The beauties of the landscape are (simply) sublime.'

The adjectives in (55) may occur in prenominal as well as in postnominal position, as shown by (57).

(57) a. $\{$ une / des $\} \quad$ (incroyable(s)) stupidité(s) (incroyable(s))

\{a / INDEF.PL $\} \quad$ (incredible(PL)) stupidity(PL) (incredible(PL))

Lit.: '\{one /ø\} incredible \{stupidity/ stupidities\}', i.e. \{one /ø\} incredibly stupid word(s)

b. $\{$ une $/$ des $\} \quad$ (impardonnable(s)) méchanceté(s) (impardonnable(s))

$\{\mathrm{a} / \mathrm{INDEF} . \mathrm{PL}\} \quad$ (unforgivable(PL)) wickedness(PL) (unforgivable (PL))

Lit.: '\{one $/ \varnothing\}$ unforgivable wickedness(es)', i.e. \{one $/ \varnothing\}$ unforgivable wicked word(s) 


$$
\begin{array}{llll}
\text { c. }\{\text { une } / \text { des }\} & \text { (sublime(s)) } & \text { beauté(s) } & \text { (sublime (s)) } \\
\{\mathrm{a} / \text { INDEF.PL }\} & (\text { sublime(PL)) } & \text { beauty(PL) } & \text { (sublime(PL)) }
\end{array}
$$

They also allow an evaluative reading, impardonnable 'unforgivable' being construed as 'very serious', and incroyable 'incredible' as 'enormous'. Since they pattern like gracieuse 'graceful' and épuisante 'exhausting' with activity nominals (34), they deserve the same analysis, i.e. that of direct modifiers.

Consequently, the structure proposed in (29a) for qualifying modification of activity nominals in count use can also be used for the examples in (55), as shown in (58). When the adjectives occur postnominally, we will consider that NumP has moved to Spec FP (58c), as with activity nominals.

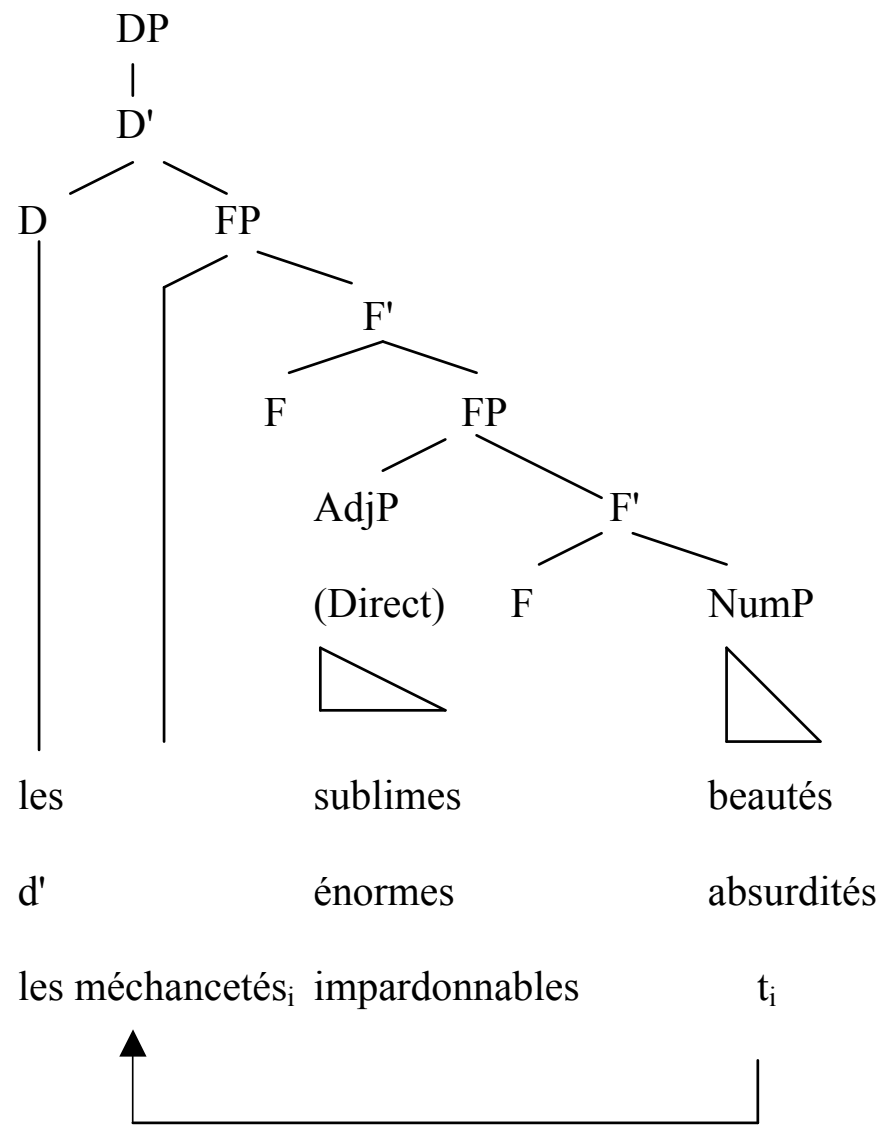

\subsection{Modified quality nominals introduced by the partitive article}

Let us now examine structures in which modified quality nominals are introduced by the partitive article. Recall from Section 3.1. that quality nominals lack NumP in their mass use. As a consequence, the adjectives modifying them can only merge above ClassP.

Now, concerning quality nominals referring to states, the question of a potential event structure has to be raised. According to Kratzer (1996), states display an event structure, syntactically encoded by a vP. Alexiadou (2011) and Borer (2005) consider that the possible insertion of for temporal adverbials proves the presence of an event structure. In the same vein, Grimshaw (1990) considers that modifiers such as constant, frequent, or subordinate clauses introduced by in order to reveal the presence of an event structure, which distinguishes event nominals, whether simple or complex, from results. The following examples show that quality nominals pass all these tests successfully:

\footnotetext{
a. sa méchanceté \{constante/ délibérée\} his/her wickedness \{constant/ deliberate\} 'his/her constant / deliberate wickedness'
} 

b. son agressivité fréquente
his/her aggressivity frequent
'his/her frequent aggressivity'
c. la gentillesse de Paul dans le but d' amadouer Marie
the kindness of Paul in order to coax Mary
Lit.: 'Paul's kindness in order to coax Mary'
d. sa patience pendant tout le voyage
his/her patience for all the trip
'his/her patience for the whole trip'

Consequently, we suggest that quality nominals, like activity nominals, merge under a ClassP dominating a vP projection:

(60)

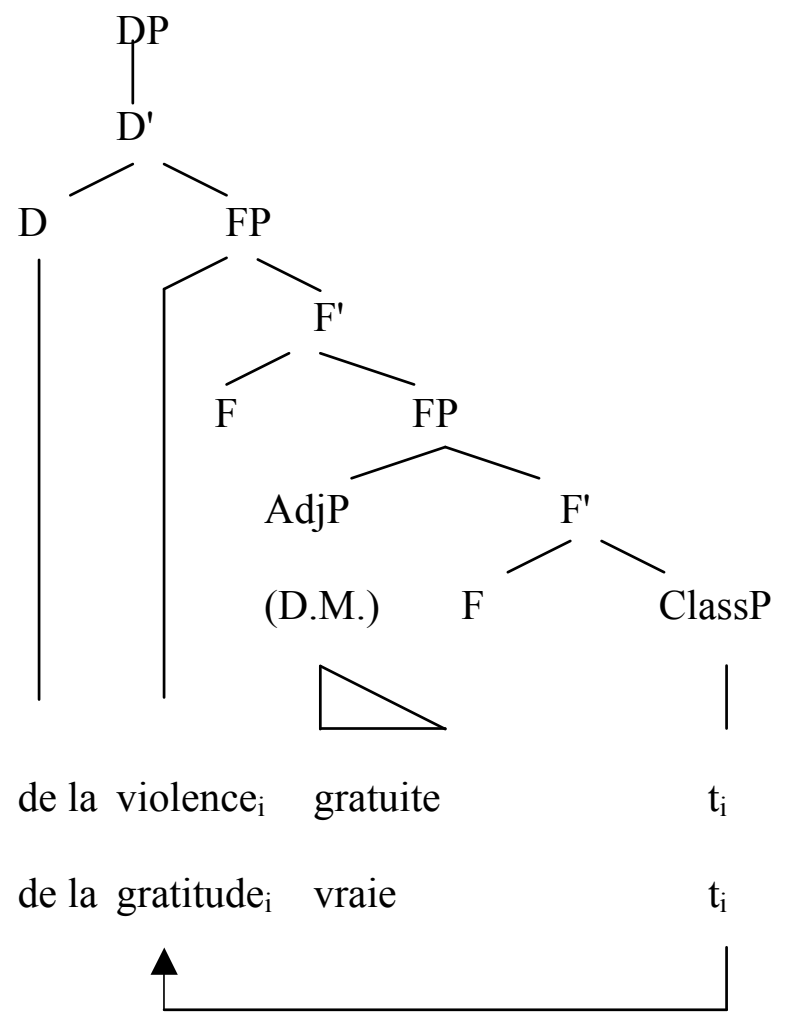

However, another possible question is why such structures are frequently considered unacceptable. In our opinion, this may be due to the fact that, in contrast to activity nominals or simple nouns, quality nominals do not present natural (i.e. objective) subclasses. According to Flaux \& Van de Velde $(2000,77)$, qualities correspond to the final (i.e. lowest) elements of their taxonomy, and, as such, cannot be questioned by quel 'which':

$$
\begin{aligned}
& \text { ?? Quel courage as-tu? } \\
& \text { what courage have-you }
\end{aligned}
$$

Lit.: 'What (kind of) courage do you have?'

In our view, this property is inherited from the corresponding adjectives, which do not allow subclassification, in contrast to colour adjectives, for example (62a):
a. $-\mathrm{De}$
quel bleu est
which blue is
ta nouvelle
your new
voiture?
- of
which blue is your new
car 
- Elle est \{bleu marine / bleu outremer / bleu azur / ...

- it is \{blue navy/ blue ultramarine / blue sky / ...

'- Which blue is your new car?

- It is \{navy blue / ultramarine blue / sky blue / ... \}'

vs.:b.?? - De quelle \{méchanceté / douceur / bonté/ violence / ... \} a-t-elle fait preuve?

- of which \{wickedness / gentleness / goodness/violence/...\} has she shown

'- Which \{wickedness / gentleness / goodness / violence / ...\} did she show?'

Since quality nominals do not display natural / objective subclassification, in this case, only adjectives expressing an already recognized form of the property can allow a taxonomic, i.e. subsective reading, and, consequently, accept the partitive article ${ }^{10}$. The reduced frequency of such strings is thus explained, and accounts for the common judgement that these structures are illformed.

\subsection{Modified nominals introduced by the indefinite article}

As we saw in the above sections, the partitive article is possible only with a reduced class of adjectives. Compare the following examples, in which the partitive article is unacceptable, to those in (53):
a. Il a montré $\{$ un $/ * \mathrm{du}\}$ grand courage

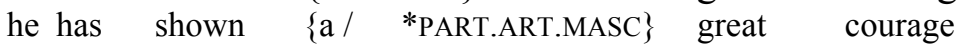 'He has shown a great courage.'
b. Elle a manifesté $\{$ une/ *de la\} patience exceptionnelle she has exhibited $\{\mathrm{a} / \quad$ *PART.ART.FEM $\}$ patience exceptional 'She has shown an exceptional patience.'
c. $\mathrm{Tu}$ as fait preuve $\left\{\mathrm{d}^{\prime} u n e / * \mathrm{~d}^{\prime}\right\} \quad$ incroyable stupidité you have exhibited $\{$ of a / *of $\}$ incredible stupidity
'You have shown incredible stupidity.'

The adjectives grand 'great', exceptionnelle 'exceptional' and incroyable 'incredible' have the same properties as those of examples (34-35), where they modify count activity nominals. Apart from grand which is strictly prenominal, they may occur either pre- or postnominally, and have an intensive value. Thus, the primary reading of e.g. une incroyable stupidité 'an incredible stupidity' is not 'a stupidity that cannot be believed' but 'a great stupidity'. Consequently, they qualify as evaluative adjectives in Cinque's (2010) terms, and deserve to be analyzed as direct modifiers.

In contrast, inespéré 'unexpected' and injustifié 'unjustified', which occur only postnominally and have no evaluative reading, qualify as indirect modifiers:

(64) a. Ils ont montré \{un courage inespéré/ une méchanceté gratuite\} they have shown \{a courage unexpected/a wickedness gratuitous $\}$ 'They have shown \{an unexpected courage / a gratuitous wickedness\}'
b. *Ils ont montré \{un inespéré courage/ une gratuite méchanceté\} they have shown an unexpected courage/ a gratuitous wickedness $\}$

Recall from (53c) that méchanceté gratuite 'gratuitous wickedness' can also be introduced by the partitive article, in this case referring to a previously established form of wickedness. When the indefinite is used instead of the partitive, the semantic difference lies in the fact that the adjective is used to qualify the wickedness exhibited in a particular situation, in other words, a particular instance of wickedness.

Consequently, we can conclude that modification of quality nominals parallels modification of activity nominals; in both cases, we find direct modifiers with a taxonomic / subsective value that 
accept the partitive article, and others that allow an evaluative reading and are only compatible with the indefinite $u n$. However, only examples of evaluative adjectives modifying activity nominals have been provided until now. Since evaluative (63), as well as indirect modifiers (64), are able to modify quality nominals in mass use, the same should be true for nouns denoting activities. The following examples (from a daily local newspaper and the Internet 'France' pages) show that this is indeed the case. Note that savoureuse 'tasty' (65), as a direct modifier, occurs either pre- or postnominally, and generally means 'very good' rather than 'that has a lot of (good or bad) taste'. Examples (66) are cases of indirect modification.
a. Yannick pratique une cuisine savoureuse. Yannick practices a cooking tasty
'Yannick practices a tasty cuisine'
b. ...où l'on pratique une savoureuse cuisine de terroir ...where one practices a tasty cooking of country
'...where one practices a tasty traditional local cuisine'
c. il a pratiqué \{un sérieux décapage/ un décapage sérieux\} he has practised $\{\mathrm{a}$ serious scouring/ a scouring serious\}
Lit.: 'He undertook a serious scouring.' (i.e. a strong scouring)
a. Ce jeune homme [...] pratique une danse plutôt méconnue du grand this young man $[\ldots]$ practices a dance rather unknown of.the large public audience Lit.: 'This young man practices a dance (that is) rather unknown by a large audience.'
b. Il y pratique un jardinage respectueux de la nature he there practice a gardening respectful of the Nature Lit.:'He practices there gardening respectful of Nature.'

cf. c. *Il pratique \{une méconnue danse / un respectueux jardinage\}

We are now able to provide a description of the combination of adjectives and determiners for activity as well as quality nominals. When in count use, both classes accept any class of adjectival modifiers, i.e. direct taxonomic and non-taxonomic, and indirect. When in mass use, only subsective / taxonomic modification allows the partitive article to be used; conversely, nonsubsective direct as well as indirect modifiers coerce the replacement of the partitive by the indefinite $u n(e)$, a fact that deserves taking into account.

In fact, both Kleiber (2003) and Kupferman (2004) attempted to provide a semantic explanation for this constraint.

According to Kupferman (2004), the referent of the modified mass noun has to stand in a partwhole relation with that of another noun in the sentence for un(e) to appear in the case of modification by a characterizing adjective (a qualifying adjective in our terms); this is indeed the case in the following example where eau 'water' is necessarily understood as eau du lac 'lake water':

$\begin{array}{llll}\text { (67) Le lac avait ce jour-là }\{\text { une } / * \text { de l'\} } & \text { eau verdâtre. } \\ \text { the lake had that day } & \text { a } / & \text { *PART.ART.FEM }\} \text { water greenish }\end{array}$

Lit.: 'The lake had that day a greenish water.' (Kupferman 2004, 77)

Kupferman applies this analysis to quality nominals, which he analyzes as abstract parts of (human) referents, as exemplified by the parallel between (67) and (68) (see also Van de Velde 1995, Flaux \& Van de Velde 2000, Beauseroy \& Knittel 2007, Beauseroy 2009): 
(68) Notre concierge manifestait une grande éloquence

our concierge exhibited a great eloquence

Lit.: 'Our concierge exhibited a great eloquence.' (Kupferman 2004, 87)

Yet, the condition requiring a part-whole relationship seems to be too strong for activity nominals (65-66), which cannot be analyzed in this way.

On the other hand, Kleiber's (2003) explanation relies on the idea that the instance of the modified noun has to be delimited spatiotemporally for un(e) to appear. In the case of example (67), it is precisely the reference to lac 'lake' that enables the spatiotemporal delimitation of the noun's (i.e. eau 'water') referent. This spatiotemporal delimitation is what distinguishes this kind of structure from those where the adjective enables reference to a subkind. In (67), the adjective is used to qualify a precise instance of spatiotemporally delimited water. The result of this process is to bring about an individualizing reading ${ }^{11}$, as Kleiber calls it, which, in turns, entails a specific reading of the noun eau 'water'.

However, this explanation is only partially valid, since modified nominals introduced by un(e) can also be found as generic subjects, which are not spatiotemporally anchored ${ }^{12}$ :
a. Une grande patience est nécessaire avec les enfants
a great patience is necessary with the children Lit.: 'A great patience is necessary with children'
b. Un vrai courage permet de braver toutes les épreuves
a true courage allows to face all

Lit.:'A true courage allows facing all the ordeals.'

Leaving aside the idea of spatiotemporal delimitation, and taking Kleiber's argument the other way round, we suggest that the partitioning of a mass referent is a necessary condition for a nonsubsective adjective to appear, this partitioning effect being due to the presence of NumP, as suggested by Borer (2005, Chapter 4). According to Borer, $\mathrm{NumP}^{13}$ is fundamentally a partitioning projection; its effect is to divide nouns, which primarily denote mass entities, into individuals, thus enabling the identification of particular occurrences of a given mass noun. In the cases under examination here, the occurrence of the mass noun distinguished by NumP is then given a particular qualitative feature by the adjective, giving rise to a referent distinct from that which is referred to by the unmodified noun. Still following Borer's analysis, we can consider that the indefinite singular article, which has both a dividing and a counting function, by contrast with other numerals, is generated under NumP and moved to the position of quantifiers, \#P. On the other hand, Cinque (2010) suggests that weak indefinites merge under a specific projection labelled dP, which is inserted between the FPs of direct and indirect modification.

Taking both analyzes into account, we suggest that $u n(e)$ is generated under NumP and moved to $\mathrm{dP}$, as in (70): 
(70)

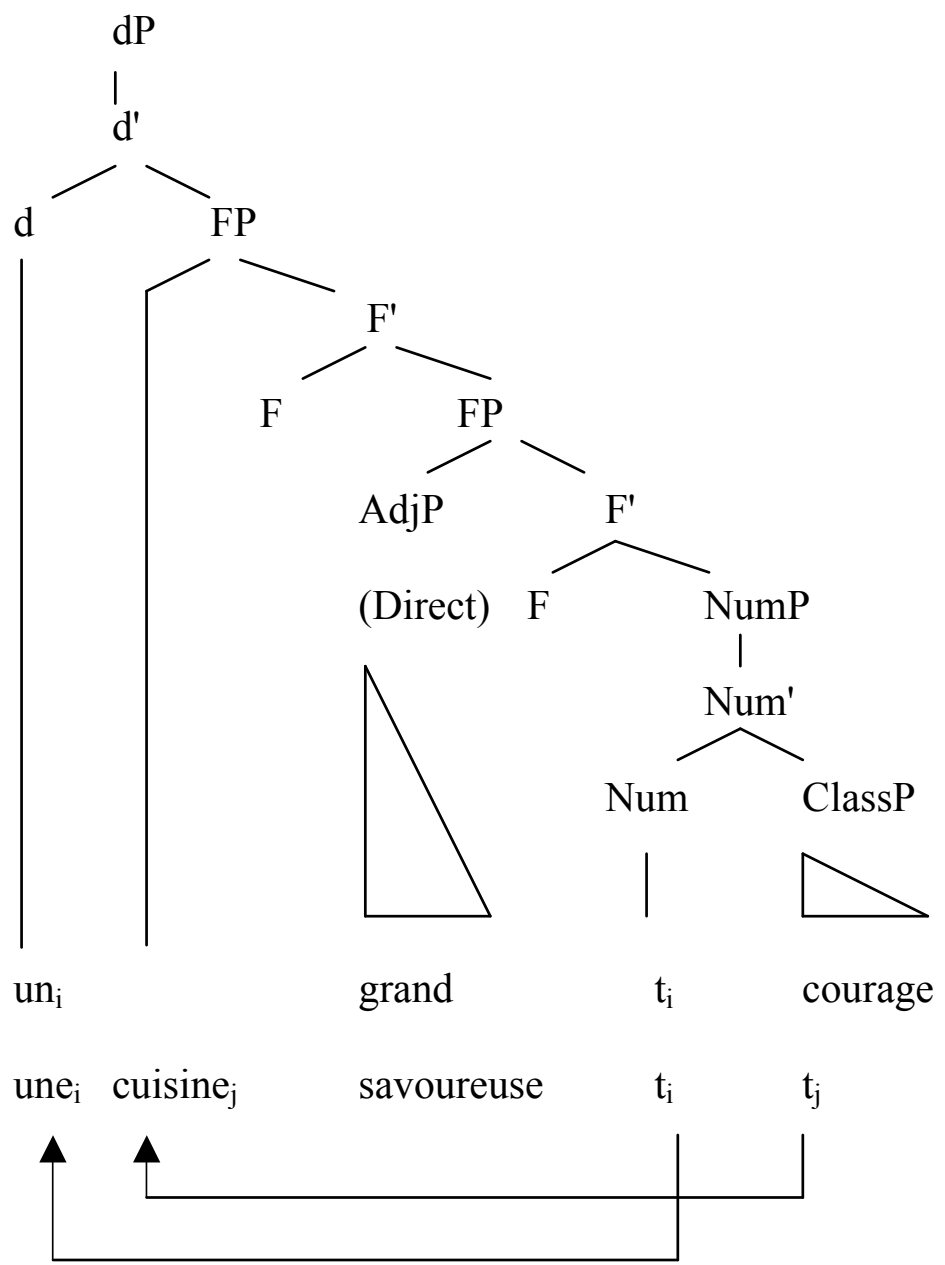

This analysis also accounts for indirect modification, the only difference being that the adjectival projections merge above $\mathrm{dP}$. 
(71)

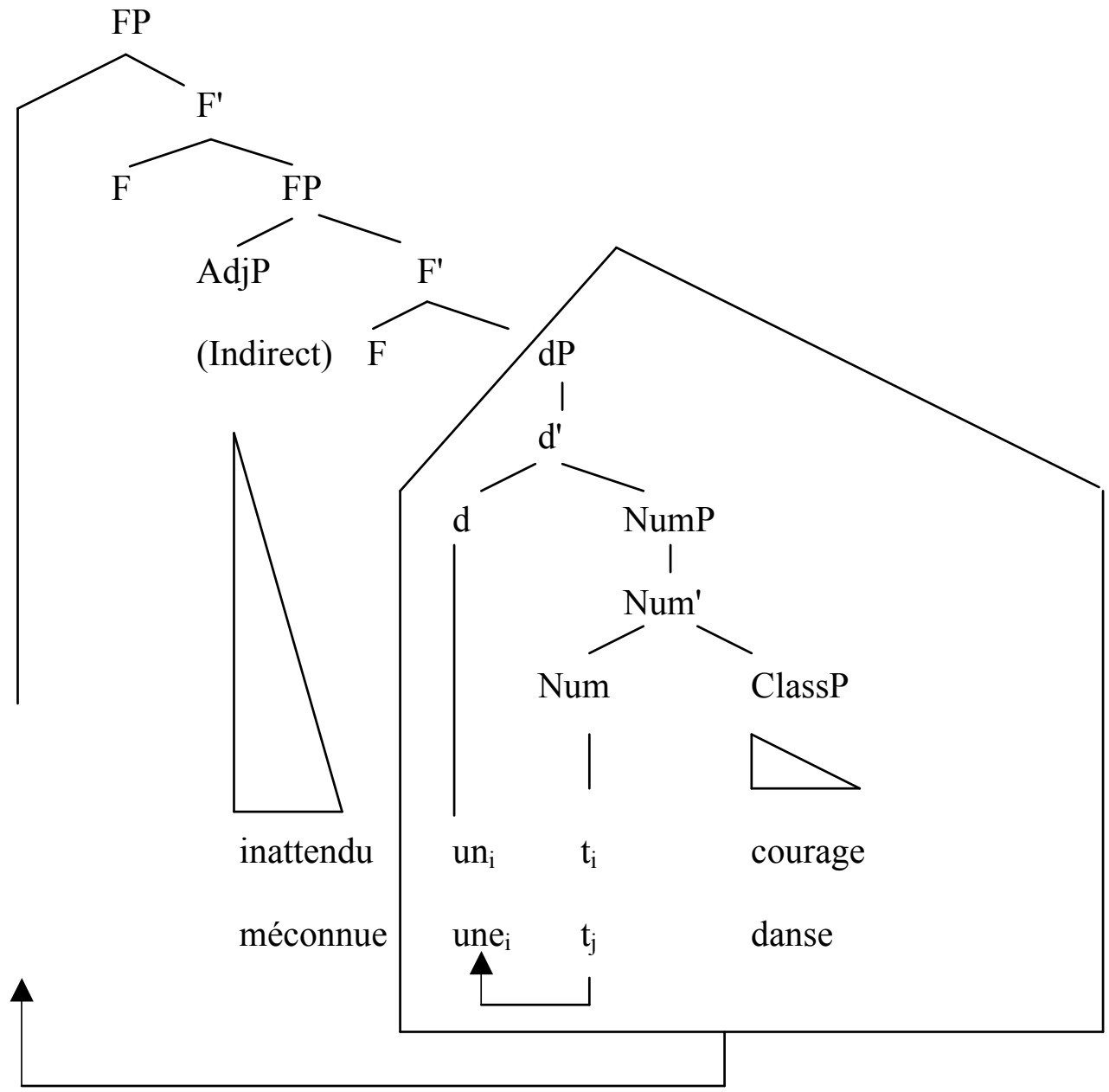

Finally, the above analysis raises the question of the status of the partitive article. As we have seen above, this determiner appears with activity and quality nominals in two cases: when they are unmodified or when they are associated with taxonomic / subsective adjectives.

The major morphosyntactic peculiarity of the partitive lies in the fact that it is made up of two parts: de, originally a preposition (see Carlier 2007), which is considered as a quantifier by Kupferman (2004) and Zribi-Hertz (2006), and a definite article, la in the feminine and le in the masculine, $d e+l e$ being expressed as $d u^{14}$. Following Kupferman, and in the terms of our analysis, let us assume that $d e$, as a quantifier, merges under $\mathrm{dP}$. Now, despite the fact that le / la have the form of definite articles, they cannot allow such an analysis when they occur in partitives, which are indefinites ${ }^{15}$. One possible interpretation is that they are gender markers since, in French, in contrast to Italian or Spanish, for example, nouns do not exhibit gender marking, gender being only expressed by the article form in the singular. As such, they could merge under ClassP, and then move to $\mathrm{dP}$, giving rise to the partitive, as shown below (72): 
(72)

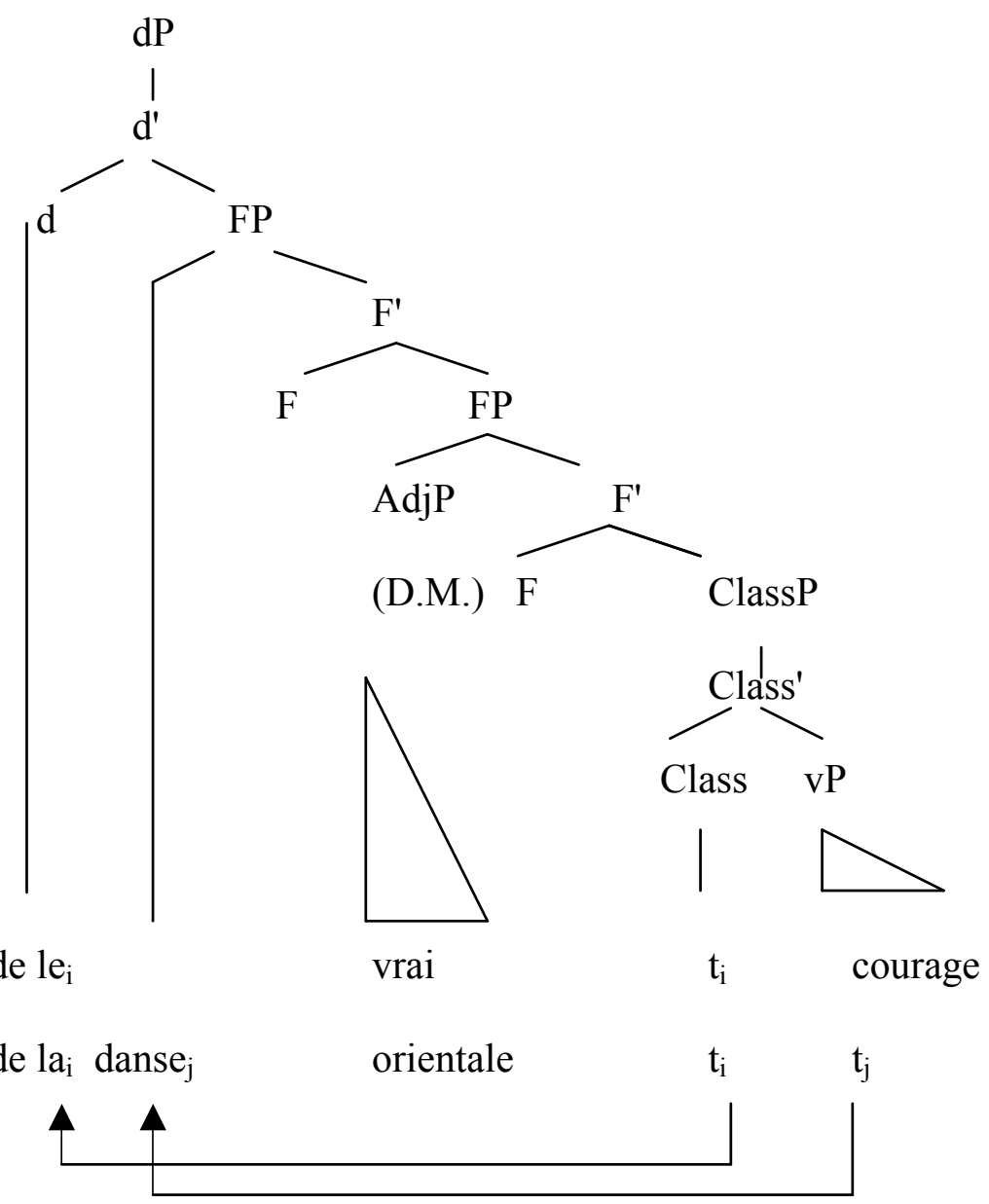

\section{CONCLUSION}

In this article, we have argued that an accurate description of French modified abstract nouns such as quality and activity nominals must rely on the interaction between the presence of NumP, $\mathrm{dP}$ and the positions of adjectival projections in the functional structure of the noun.

We first showed that qualifying modification, whether direct or indirect in Cinque's (2010) terms, occurs only if the nouns exhibit number inflection, that is, when NumP is present in the functional nominal structure. Since NumP is restricted to activity and quality nominals with a specific interpretation, that is, to nouns occurring in non-generic and non-incorporated contexts, qualifying modification is restricted to such uses.

In contrast, taxonomic modification, which corresponds to the expression of subkinds, is independent of the presence of NumP and does not rely on the interpretation the quality and activity nominals receive. To account for these distributional properties, we hypothesize that, whereas taxonomically used adjectives select the nominal projection ClassP, qualifying adjectives necessarily select NumPs as their complements.

Yet activity and quality nominals also accept direct and indirect qualifying modification while keeping their eventive interpretation, provided they are introduced by the singular indefinite article instead of the partitive. Elaborating on Borer's (2005) analysis, we propose that the indefinite un(e), which merges under NumP, allows partitioning of the mass referent. In this case, the adjective qualifies the instance of the noun distinguished by the means of un(e).

A final desirable consequence of the analysis proposed here is that no special stipulation is needed to account for the behaviour of quality and activity nominals with regards to modification, since it arises from independent adjectival (i.e. taxonomic vs. qualifying reading) and nominal (i.e. the mass / count distinction) properties. 


\section{REFERENCES}

ABNey, S. 1987. The Noun Phrase in its Sentential Aspect. Ph.D.Dissertation, MIT.

ALEXIADOU, A. 2009. On the role of syntactic locality in morphological processes: the case of (Greek) derived nominals. Quantification, Definiteness and Nominalization, ed. A. Giannakidou \& M. Rathert, 253-280. Oxford: Oxford University Press.

ALEXIADOU, A. 2011. Statives and nominalizations. Recherches Linguistiques de Vincennes 40.

BEAUSEROY, D. 2009. Syntaxe et sémantique des noms abstraits statifs : des propriétés verbales et adjectivales aux propriétés nominales. Thèse de Doctorat, Nancy-Université /ATILF CNRS.

Beauseroy, D. \& KnitTel, M. L. 2007. Nombre et détermination : le cas des noms abstraits de qualité". Rivista di Linguistica 19-2, 231-262.

BITTNER, M. 1988. Canonical and non-canonical argument expressions. Doctoral dissertation, University of Texas, Austin.

BOLINGER, D. 1967. Adjectives in English: attribution and predication. Lingua 18, 1-34.

BORER, H. 2005. Structuring Sense, volume I: In Name Only. Oxford: Oxford University Press.

CARLIER, A.2007. From preposition to article: the grammaticalization of the French partitive.

Studies in Language 31-1, 1-49.

CARstens, V. 1991. The Morphology and Syntax of Determiner Phrases in Kiswahili. Ph.D. Dissertation, UCLA.

Chung, S. \& LAdusaw, W. 2003. Restriction and saturation. Cambridge (MA): MIT Press.

CINQUE, G. 1994. On the evidence for partial N movement in the Romance DP. Paths towards Universal Grammar: Studies in Honor of Richard S. Kayne, ed. G. Cinque et al., 85-110. Washington DC: Georgetown University Press.

CINQue, G. 2008. More on the indefinite character of the Head of restrictive relatives. Rivista di grammatica generativa 33, 3-24.

CINQUE, G. 2010. The syntax of adjectives: a comparative study. Cambridge, MA: MIT Press.

DAVIDSON, D. 1967. The logical form of action sentences. The logic and decision and action, ed. N.

Rescher, 20-81. Pittsburgh: University of Pittsburgh press.

Dobrovie-Sorin, C. \& LACA, B. 2003. Les noms sans déterminants dans les langues romanes. Les langues romanes, problèmes de la phrase simple, ed. D. Godard, 235-279. Paris: CNRS Editions.

FARKAS, D. \& SWART, H. de. 2003. The semantics of incorporation: from argument structure to discourse transparency. Stanford: CSLI Publications.

FlaUX, N. \& VAN DE VELDE, D. 2000. Les noms en français: esquisse de classement. Paris: Ophrys.

Fradin, B. \& KerlerouX, F. 2003. Quelles bases pour les procédés de la morphologie constructionnelle ?. Silexicales 3: les unités morphologiques, ed. B. Fradin et al, 76-84. Villeneuve d'Ascq : Presses Universitaires du Septentrion.

Fradin, B. \& Kerleroux, F. 2009. L'identité lexémique. Aperçus de morphologie du français, ed. B. Fradin, F. Kerleroux \& M. Plénat, 85-104. Saint-Denis: Presses Universitaires de Vincennes.

GeEnhoven, V. van. 1998. Semantic incorporation and indefinite descriptions: Semantic and syntactic aspects of noun incorporation in West Greenlandic. Stanford: CSLI.

Grimshaw, J. 1990. Argument structure. Cambridge (MA): MIT Press.

GROSS, M. 1967. Sur une règle de cacophonie. Langages 7, 105-119.

HAAS, P. \& HuYGHE, R. 2007. Les propriétés aspectuelles des noms d'activités. Conference given at the AFLS colloquium. Boulogne-sur-mer, September 3-5 2007.

HAAs, P., HuYGHe, R. \& MARin, R. 2008. Du verbe au nom : calques et décalages aspectuels. Actes du Congrès Mondial de Linguistique Française, ed. J. Durand, B. Habert \& B. Laks, 2039-2053. Paris: Institut de Linguistique Française. 
HAegeman, L. 2003. La distribution du verbe et du nom en français et en anglais. Essais sur la grammaire comparée du français et de l'anglais, ed. P. Miller \& A. Zribi-Hertz, 55-95. SaintDenis: Presses Universitaires de Vincennes.

HARLEY, H. 2009. The morphology of nominalizations and the syntax of vP. Quantification, Definiteness, and Nominalization, ed. A. Giannakidou \& M. Rathert, 321-343. Oxford: Oxford University Press.

Heyd, S. \& KNITTEL, M.L. 2009. Les noms d'activités parmi les noms abstraits: propriétés aspectuelles, distributionnelles et interprétatives. Lingvisticae Investigationes 32-1, 124 - 148.

Hoop, H. de. 1992. Case configuration and NP interpretation. Doctoral dissertation, Rijks Universiteit, Groningen.

IORDĂCHIOAIA, G. \& SOARE, E. 2009. Structural patterns blocking plural in Romance nominalizations. Romance Languages and Linguistic Theory, Selected papers from Going Romance Amsterdam 2007, ed. E. Aboch, E. van der Linden, J. Quer \& P. Sleeman, 145-160. Amsterdam: John Benjamins.

KLEIBER, G. 2003. Indéfini, Partitif et Adjectif : du nouveau. La lecture individualisante. Langages 151, 9-28.

KNITTEL, M.L. 2005. Some remarks on adjective placement in the French NP. Probus 17-2, 185227.

KNitTel, M.L. 2009. Le statut des compléments du nom en [de NP]. Revue Canadienne de Linguistique 54-2, 255-290.

KNitTel, M.L. 2010. Possession vs. incorporation in the nominal domain: evidence from Fench event nominal dependencies. The Linguistic Review 27-2, 177-230.

KrATZER A. 1996. Severing the External Argument from its Verb. Phrase structure and the lexicon, ed. J. Rooryck \& L.A. Zaring, 109-137. Dordrecht: Kluwer.

KUPFERMAN, L. 2004. Le mot de: domaines propositionnels et domaines quantificationnels. Brussels: De Boeck.

KwON, S. \& ZRIBI-HertZ, A. 2004. Number from a syntactic perspective: why plural marking looks 'truer' in French than in Korean. Empirical Issues in Syntax and Semantics 5, ed. O.Bonami \& P. Cabredo-Hofherr. http://www.cssp.cnrs.fr/eiss5/index_en.html.

LAENZLINGER, C. 2005. French adjective ordering: perspectives on DP-internal movement types. Lingua 115-5, 645-689.

LAmarche, J. 1991. Problems for $\mathrm{N}^{\circ}$-movement to NumP. Probus 3-2, 215-236.

LARSON, R. 1998. Event and modification in nominals. Proceedings from Semantics and Linguistic Theory (SALT) VIII, ed. D. Strolovitch \& A. Lawson, 145-168. Ithaca (NY): Cornell University Press.

MASSAM, D. 2001. Pseudo-incorporation in Niuean. Natural Language and Linguistic Theory 19, 153-197.

MATHIEU, E. 2004. The mapping of form and interpretation: The case of optional WH Movement in French. Lingua 114, 1090-1132.

MATHIEU, E. 2006. Bare nouns and morpho-syntactic reflexes of semantic incorporation: Some new facts. Proceedings of the Thirty-Fifth Annual Meeting of the North East Linguistic Society (NELS 35), ed. L. Bateman \& C. Ussery, 403-418. Charleston: BookSurge Publishing.

MCNAlly L. \& BoledA G. 2004. Relational adjectives as properties of kinds. Empirical Issues in Syntax and Semantics 5, ed. O. Bonami \& P. Cabredo-Hofherr. http://www.cssp.cnrs.fr/ eiss5/index en.html.

OBENAUER, H.G. 1983. Une quantification non canonique : la "quantification à distance". Langue Française 48, 66-88.

PICALLO, C. 2008. Gender and number in Romance. Lingue e linguaggio VII.1, 47-66.

PIVAUT, L. 1994. Quelques aspects sémantiques d'une construction à verbe support faire. Lingvistica Investigationes XVIII-1, 49-88. 
PolinsKy, M. 1992. Maori he revisited. Oceanic Linguistics 31, 229-250.

RAINER, F. 1989. I nomi di qualità nell 'italiano contemporaneo. Vienna: Braunmüller.

RITTER, E. 1991. Two functional categories in noun-phrases: evidence from Modern Hebrew. Syntax and Semantics 26, ed. S. Rothstein, 37-62. San Diego: Academic Press.

SHLONSKY, U. 2004. The form of semitic noun phrases. Lingua 114, 1465-1526.

SMITH, C. S. 1991. The parameter of Aspect. Dordrecht : Kluwer.

SproAT, R. \& SHIH, C. 1990. The cross-linguistic distribution of adjective ordering restrictions. Interdisciplinary approaches to Language: Essays in Honor of S.Y.Kuroda, ed. C. Georgopoulos \& R. Ishihara, 565-593. Dordrecht: Kluwer.

VALOIS, D. 1991. The internal syntax of DP and adjective placement in French and English. NELS 21, 367-382.

VAN DE VELDE, D. 1995. Le spectre nominal : des noms de matière aux noms d'abstraction. Paris: Peeters.

VendLeR, Z. 1967. Linguistics in Philosophy. Ithaca (NY): Cornell University Press.

VERKUYL, H. 1972. On the compositional nature of aspect. Dordrecht : Reidel.

Zribi-HertZ, A. 2006. Pour une analyse unitaire de DE partitif. Actes du colloque indéfinis et prédication, ed. F. Corblin, S. Ferrando \& L. Kupferman, 141-154. Paris: Presses Universitaires de Paris-Sorbonne.

Zribi-Hertz, A. \& Glaude, H. 2007. Bare NPs and deficent DPs in Haitian and French: from morphosyntax to referent construal. Bare Nouns in Creole Languages, ed. M. Baptista \& J. Guéron, 265-298. Amsterdam \& Philadelphia: John Benjamins. 


\section{ENDNOTES}

${ }^{1}$ Some nouns can be preceded by a definite article in such contexts; in these cases, the sentences can exhibit telic aspect, depending on the noun:

(i) J'ai fait \{le ménage / la lessive / la vaisselle $\}$ en dix minutes.

I have done \{the housework / the laundry/ the dishes\} in ten minutes

'I did \{the housework / the laundry / the dishes\} in ten minutes.'

(ii) J'ai fait \{le ménage / la cuisine $\}$ pendant une heure.

I have done \{the housework / the cooking for one hour

'I did \{the housework / the cooking\} for one hour.'

2 'Taxonomic' is synonymous with Knittel's (2005) 'typifying', and corresponds roughly to the label 'classifying' used in Kupferman (2004).

${ }^{3}$ From a semantic point of view, danse in (17a) and marche in (17b) allow a resultative rather than an eventive reading. Yet, since they accept aspectual modification (cf. les marches régulières 'the regular walks'), they cannot be classified in Grimshaw's (1990) 'result nominals' class. In (17c), the nouns are understood as the instruments required to practise the sport (moto, cheval) or artistic activity (piano).

${ }^{4}$ In negative contexts, de alone is generally used instead of the full form (i.e. de +definite article) of the partitive article to introduce mass nouns. The partitive article can however be used in contrastive contexts:

(i) Je n'ai pas fait de la danse, mais du jardinage

I Neg-have not done PART.ART.FEM dance, but PART.ART.MASC gardening

'I have not done any dancing, but some gardening'.

${ }^{5}$ Incorporated nouns generally appear without a determiner. Yet, cases of determinerless nouns are very restricted in French: partitive articles are used where other languages use bare nouns, as shown by Dobrovie-Sorin \& Laca (2003). Consequently, we can hypothesize that the presence of the partitive article does not prevent incorporation in French, a situation reminiscent of Maori, where a particular determiner is used with incorporated nominals (Polinsky 1992, Chung \& Ladusaw 2003).

${ }^{6}$ The possibility of taxonomic modification, as well as the presence of the partitive determiner discussed in section 2.2.2., shows that we are dealing with pseudo-incorporation (i.e. incorporation of maximal projections). See Massam (2001) for a discussion.

${ }^{7} \mathrm{~N}$ to Num movement was originally proposed to account for the postnominal placement of adjectives (Cinque 1994) and noun complements (Valois 1991) in Romance; when raising to Num, the noun would move over adjectives and complements, causing them to surface postnominally. However, as observed by Lamarche (1991) and Laenzlinger (2005), this analysis is unable to account for the adjectives that surface both pre- and postnominally, since it would imply optional $\mathrm{N}$ movement. Moreover, as noted by Laenzlinger, an XP-movement accounts more accurately for cases such as (ii), where the adjective necessarily occurs after the noun's complement:

(i) une immense maison / une maison $_{\mathrm{i}}$ immense $\mathrm{t}_{\mathrm{i}}$

'a huge house'

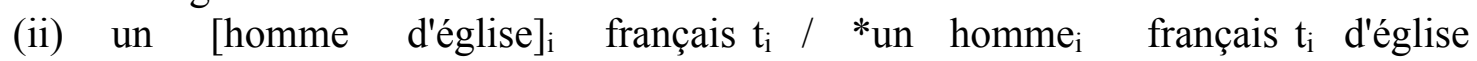
a man of church French / a man French of church 'a French clergyman' 
${ }^{8}$ Note however that beaucoup can receive allows the habitual reading of souvent 'often' when combined with an S-level adjectival predicate:

(i) a. Il est beaucoup malade (ces temps-ci). he is a lot ill (these times)

Lit: 'He has been a lot ill these days.'

$=\mathrm{b}$. Il est souvent malade (ces temps-ci). he is often ill (these times)

'He is often ill these days.'

9 As shown in (52b), the partitive article is not realized phonologically when it follows the preposition $d e$ 'of', due to the so-called 'cacophony rule' already observed by the Port-Royal grammarians in the 17th century (see Gross 1967). This prepositional de should not be confused with the reduced form of the partitive article, which also surfaces as de in (52d) due to negation (see note 3$)$.

${ }^{10}$ Modification of generics by such adjectives is possible, providing a further argument in favour of our analysis. However, since the partitive is generally impossible in subject position, such strings are introduced by the definite article:

(i) La vraie gratitude est rare.

the true gratitude is rare

'True gratitude is rare.'

${ }^{11}$ Our translation of lecture individualisante.

${ }^{12}$ We thank the anonymous reviewer of Studia Linguistica for having pointed this out.

${ }^{13}$ Borer labels this projection CLP.

${ }^{14} d e$ also enters in the plural indefinite article form, which is realized as des in the unmarked cases. This form can be accounted for by considering that $d e$ is combined with the plural marker $-s$ merged under NumP and moved to $\mathrm{dP}$, the gender marker generally being neutralized in the plural forms of French determiners.

${ }^{15}$ For the string $d e+l a$ in a sentence such as (i), there are two different underlying structures, distinguished by their interpretations:

(i) J'ai mangé de la glace

(a) I ate some ice cream.

(b) I ate some (part of) the ice cream.

The partitive article proper only occurs in the structure corresponding to the (a) reading. When (i) receives the (b) reading, $l a$ is a definite determiner, and alternates with other determiners: ' $j$ 'ai mangé de \{ta / cette\} glace': I ate some (part of) \{your / this\} ice cream.) De is closer to a preposition, as show by the fact that it has to occur with the corresponding interrogative pronoun, see the contrast in (ii) / (iii):

(ii) De quoi as-tu mangé?

Lit.: 'Of what did you eat?'

(iii) Qu'as-tu mangé? [(a) reading]

'What did you eat?'

[(b) reading]

See Kupferman (2004), Zribi-Hertz (2006) for a discussion. 